\title{
Chemical characterization of territorial marking fluid of male Bengal tiger, Panthera tigris
}

\author{
B. V. Burger, M. Z. Viviers, M. Le Roux \& N. Fish \\ Laboratory for Ecological Chemistry, University of Stellenbosch, Private Bag X1, Matieland, 7602, South Africa \\ J. P. I. Bekker \\ Institute for Plantbiotechnology, Private Bag X1, Matieland, 7602, South Africa \\ W. B. Fourie \\ Tygerberg Zoo, P.O. Box 524, Kraaifontein, 7569, South Africa \\ G. Weibchen \\ Institut für Organische Chemie, Universität Hamburg, Martin-Luther-King-Platz 6, 20146 Hamburg, Germany
}

\begin{abstract}
The territorial marking fluid of the male Bengal tiger, Panthera tigris, consists of a mixture of urine and a small quantity of lipid material that may act as a controlled-release carrier for the volatile constituents of the fluid. Using gas chromatography and gas chromatography-mass spectrometry, 98 volatile compounds and elemental sulfur were identified in the marking fluid. Another 16 volatiles were tentatively identified. The majority of these compounds were alkanols, alkanals, 2-alkanones, branched and unbranched alkanoic acids, dimethyl esters of dicarboxylic acids, $\gamma$ - and $\delta$-lactones, and compounds containing nitrogen or sulfur. Several samples of the marking fluid contained pure (R)-3-methyl-2-octanone, (R)-3-methyl-2-nonanone, and (R)-3-methyl-2-decanone, but these ketones were partly or completely racemized in other samples. The $\gamma$-lactone $(S)-(+)-(Z)-6$-dodecen-4-olide and the $C_{8}$ to $C_{16}$ saturated $(R)-\gamma$-lactones and $(S)$ - $\delta$-lactones were present in high enantiomeric purities.

The chiral carboxylic acids, 2-methylnonanoic acid, 2-methyldecanoic acid, 2-methylundecanoic acid, and 2ethylhexanoic acid were racemates. Cadaverine, putrescine, and 2-acetylpyrroline, previously reported as constituents of tiger urine, were not detected. The dominant contribution of some ketones, fatty acids, and lactones to the composition of the headspace of the marking fluid suggests that these compounds may be important constituents of the pheromone. Although it constitutes only a small proportion, the lipid fraction of the fluid contained larger quantities of the volatile organic compounds than the aqueous fraction (urine). The lipid derives its role as controlled-release carrier of the chemical message left by the tiger, from its affinity for the volatiles of the marking fluid. Six proteins with masses ranging from 16 to $69 \mathrm{kDa}$, inter alia, the carboxylesteraselike urinary protein known as cauxin, previously identified in the urine of the domestic cat and other felid species, were identified in the urine fraction of the marking fluid.
\end{abstract}

Keywords: Bengal tiger, Panthera tigris, Semiochemical, Pheromone, Territorial marking, Mass spectrum, Chiral gas chromatography, Urinary protein, Cauxin, Lactone.

\section{Introduction}

The tiger, Panthera tigris, is the largest existing member of the Felidae. Of the six subspecies of tiger, the Bengal tiger, P. tigris tigris, occurs throughout India and Indochina (Ellerman and Morrison-Scott 1951). The wide geographical distribution implies a great adaptability to different environmental conditions; the only requisites for its survival are some vegetative cover, a supply of water, and sufficient prey (Schaller 1967). Tigers are normally solitary animals but occasionally travel in groups of four to eight (Schaller 1967). They use different sounds, postures, and gestures to communicate with each other when they are together (Leyhausen 1960). Although vocal communication is the main form of communication, they vocalize relatively infrequently (Schaller 1967).

Because of their nocturnal and solitary habits, they make extensive use of semiochemical communication, in which urine and feces appear to be the main vectors of the semiochemicals. Urine mixed with scent gland secretions is sprayed as a territorial marking fluid on conspicuous objects. Apparently, it is a common way of signaling that another tiger is in the vicinity, providing a visitor the opportunity to avoid conflict (Leyhausen and Wolff $\underline{1959}$ ). It is thought that these scent marks are a major source of information, revealing how recently a tiger has passed by, its gender, and in the case of a female, whether she is sexually receptive. Both sexes mark territories, but a male's territory may overlap several females' territories (Schaller 1967). 
Females scent mark intensively just prior to estrus. This behavior is reduced during estrus. Males, on the other hand, mark more frequently when females are in estrus than during other stages of the females' cycle (Smith et al. 1989). Another source of semiochemicals is the strong-smelling secretion produced by the anal glands, which, when mixed with the feces, is also used to mark territory. Because there is no connecting channel between the urinary tract and the anal gland (Hashimoto et al. 1963), it has been concluded that the marking fluid does not contain anal gland secretion (Brahmachary and Dutta 1987).

Brahmachary and Dutta $(\underline{1979})$ described some of the chemical and physical properties of the animal's marking fluid. 2-Phenylethylamine (Brahmachary and Dutta 1979) and 2-acetylpyrroline (Brahmachary 1996) were identified as two of the compounds responsible for the characteristic odor of the animal's urine. This odor was less persistent in the absence of the lipid fraction of the fluid (Brahmachary et al. 1990). The lipid material consists of a complex mixture of, inter alia, long-chain free and esterified saturated and unsaturated fatty acids and alcohols with carbon chains of 14 to 22 carbon atoms (Poddar-Sarkar 1996). In bioassays carried out during investigation into the semiochemical role of the urine of the cheetah, Acinonyx jubatus (Burger et al. 2006b), it was observed that whereas a male Bengal tiger showed minimal interest in the cheetah's urine and in various other odorants used as controls, it immediately attempted to overmark a mixture of a few of the synthetic constituents of its own marking fluid.

These constituents have not been reported in earlier studies on the tiger's marking fluid, suggesting that some constituents of the marking fluid were not detected in previous studies. In this paper, we report our attempts at a comprehensive chemical characterization of the volatile organic fraction of the tiger's marking fluid and results of behavioral experiments with synthetic constituents of the marking fluid, as far as this was feasible with one pair of tigers in captivity.

In what follows, the lipid and aqueous fractions of the marking fluid will be referred to as the lipid fraction and urine, respectively.

\section{Methods and Materials General}

All Pyrex glassware used in the handling of biological material and extracts and in the preparation of reference compounds was heated to $500^{\circ} \mathrm{C}$ in an annealing oven to remove traces of organic material. Dichloromethane (Pestanal Grade, Riedel-de Haën, Seelze, Germany) was analyzed by gas chromatography (GC) and found to be pure enough for extraction purposes when used in small quantities. Syringes, stainless steel needles, and other tools were cleaned by rinsing with this solvent.

\section{Collection of Marking Fluid}

A pair of Bengal tigers was available for the present study at the Tygerberg Zoo near Cape Town, South Africa. Shortly before completion of our research, the female had a cub, and although she must have been in estrus during the period the work was carried out, it is not known whether the intermittent collection of marking fluid from the male on occasion coincided with estrus in the female. Spraying behavior could not be induced in the female, but marking fluid was obtained from the 5 -year-old male as follows. One edge of an aluminum sheet $(100 \times 500 \times 2 \mathrm{~mm})$ was folded over to form a small gutter on that side.

A hole was made at one end in the bottom of the gutter while pressing the aluminum outward to form a funnel through which the marking fluid could flow into a 100-ml glass bottle. The collection device was thoroughly cleaned with soap and water, rinsed with methanol, and heated with an industrial paint stripper. The device was suspended on the outside of the steel mesh of the tiger's cage with the fluid-collecting channel facing toward the cage and at an angle that allowed the fluid to flow into the bottle. To induce the tiger to spray its marking fluid toward the collection device, various odorants (see "Results and Discussion") were applied to the back of the aluminum. Thus, a filter paper loaded with a dilute solution of a compound ( $1 \mu \mathrm{l}$ in $1 \mathrm{ml}$ of dichloromethane) or a mixture of compounds ( $10 \mu \mathrm{l}$ in $2 \mathrm{ml}$ of dichloromethane) was taped to the back of the aluminum.

The collected marking fluid was stored at $-20^{\circ} \mathrm{C}$ until it was used for the experiments.

\section{Analytical Methods}

GC analyses were carried out with Carlo Erba 4200 and 5300 gas chromatographs equipped with flame ionization detectors and split/splitless injectors, operated at $220^{\circ} \mathrm{C}$ and $280^{\circ} \mathrm{C}$, respectively, and with cool on-column injectors. Hydrogen was used as the carrier gas $\left(50 \mathrm{~cm} / \mathrm{sec}\right.$ at $\left.40^{\circ} \mathrm{C}\right)$. The capillary columns used in this project were 
manufactured in the Laboratory for Ecological Chemistry (LECUS, Stellenbosch University) and were provided with integrated retention gaps of 1 to $2 \mathrm{~m}$. Column A (glass, $40 \mathrm{~m} \times 0.25 \mathrm{~mm}$ inner diameter [i.d.]) was coated with $0.25 \mu \mathrm{m}$ of the polar stationary phase AT-1000 (FFAP equivalent), column B (glass, $40 \mathrm{~m} \times 0.25 \mathrm{~mm}$ i.d.) coated with $0.25 \mu \mathrm{m}$ of PS-089-OH (DB-5 equivalent), the enantioselective columns $\mathrm{C}$ (glass, $30 \mathrm{~m} \times 0.3 \mathrm{~mm}$ i.d.) with $0.25 \mu \mathrm{m}$ of OV-1701-OH containing $10 \%$ heptakis(2,3-di-O-methyl-6-O-tert-butyldimethylsilyl)- $\beta$-cyclodextrin), D (glass, $30 \mathrm{~m} \times 0.3 \mathrm{~mm}$ i.d.) with $0.25 \mu \mathrm{m}$ of PS-089-OH containing $10 \%$ heptakis(2,3-di-O-acetyl-6-O-tertbutyldimethylsilyl)- $\beta$-cyclodextrin, $E$ (glass, $30 \mathrm{~m} \times 0.3 \mathrm{~mm}$ i.d.) with $0.25 \mu \mathrm{m}$ of OV-1701-OH containing $10 \%$ of heptakis(2,3,6-tri-O-methyl)- $\beta$-cyclodextrin, and the preparative column $\mathrm{F}$ (fused silica, $32 \mathrm{~m} \times 0.53 \mathrm{~mm}$ i.d.) with $2.0 \mu \mathrm{m}$ of PS-255 (DB-1 equivalent).

Extracts of the urine and solutions of reference compounds were injected in split mode at a column temperature of $30^{\circ} \mathrm{C}$ to cold trap the volatiles entering the column. Column A was then programmed at $2^{\circ} \mathrm{C}$ from $40^{\circ} \mathrm{C}$ to $250^{\circ} \mathrm{C}$ (hold $10 \mathrm{~min}$ ) and column B at $2^{\circ} \mathrm{C}$ from $40^{\circ} \mathrm{C}$ to $280^{\circ} \mathrm{C}$ (hold $10 \mathrm{~min}$ ). Enantioselective columns $\mathrm{C}$ and $\mathrm{D}$ were programmed at $1^{\circ} \mathrm{C}$ from $40^{\circ} \mathrm{C}$ to $200^{\circ} \mathrm{C}$ and to $220^{\circ} \mathrm{C}$, respectively, and column $\mathrm{E}$ at $1^{\circ} \mathrm{C}$ from $40^{\circ} \mathrm{C}$ to $140^{\circ} \mathrm{C}$. The preparative column $\mathrm{F}$ was programmed with an isothermal period during which the particular target analyte was collected. Synthetic 3-methyl-2-alkanones were purified by preparative GC on column F, collecting fractions manually (Burger et al. 2008). Preparative chromatography on enantioselective column $\mathrm{C}$ gave the pure enantiomers of synthetic 3-methyl-2-octanone (10).

A sample enriched 2:1 with respect to the (R)-enantiomer with the shorter retention time on column $\mathrm{C}$ was used for the synthesis of 2-methylheptanoic acid enriched with respect to the second-eluting (R)-enantiomer. Electron impact mass spectra (EIMS) were obtained at $70 \mathrm{eV}$ on a Carlo Erba QMD $1000 \mathrm{GC}$-mass spectrometry (MS) instrument by using columns $A$ to $E$ with helium as the carrier gas $\left(28.6 \mathrm{~cm} / \mathrm{sec}\right.$ at $\left.40^{\circ} \mathrm{C}\right)$. The GC-MS interface and ion source temperatures were $250^{\circ} \mathrm{C}$ and $180^{\circ} \mathrm{C}$, respectively. Methane was used as reactant gas at a sourcechamber pressure of about $2 \times 10^{-4}$ torr to obtain low-resolution chemical ionization spectra. Quantitative analyses were done with the above GC and GC-MS instruments with on-column sample introduction, using the 11 homologous ketones from 2-heptanone to 2-heptadecanone as external standards. ${ }^{1} \mathrm{H}$ and ${ }^{13} \mathrm{C}$ nuclear magnetic resonance (NMR) spectra were recorded in $\mathrm{CDCl}_{3}$ on Varian VNMR-300 or ANOVA-400 spectrometers at $25^{\circ} \mathrm{C}$, or on a Bruker $A M X-400$ instrument at $27^{\circ} \mathrm{C}$. Chemical shifts are given in parts per million $(\delta)$ relative to $\mathrm{CDCl}_{3}(7.26$ and 77.04 ppm for ${ }^{1} \mathrm{H}$ and ${ }^{13} \mathrm{C}$ NMR, respectively).

\section{Solvent Extraction of the Volatile Organic Constituents}

The urine and lipid fractions of the marking fluid were separated by centrifuging $58.47 \mathrm{~g}$ of the collected marking fluid for $15 \mathrm{~min}$ at 3,000 rpm. The aqueous layer (urine) was removed with a syringe. During further prolonged centrifugation of the lipid fraction, the temperature of the material increased to about $30^{\circ} \mathrm{C}$, and a supernatant layer of clear, almost colorless oil was formed. This was separated from a further small volume of urine, which was combined with the previous urine fraction. The supernatant oil $(0.45 \mathrm{~g})$ and the combined urine fractions ( $58 \mathrm{~g})$ were stored at $-20^{\circ} \mathrm{C}$ until analyzed. Using centrifugation to facilitate separation of the phases, the organic material was repeatedly extracted from a sample $(33.8 \mathrm{~g})$ of the urine with 3-ml aliquots of dichloromethane, monitoring the removal of the organic material by GC-MS analysis.

The extraction was terminated after the 15th extraction cycle. The combined extracts (approximately $40 \mathrm{ml}$ ) were concentrated to about $60 \mu \mathrm{l}$ by slow evaporation of the solvent under nitrogen atmosphere, without blowing nitrogen directly into the vial containing the extract (Reiter et al. 2003). As the solvent was evaporated, the extract was transferred to increasingly smaller vials. Aliquots of $1.0 \mu \mathrm{l}$ of the concentrated solution were analyzed by GC and GC-MS. A second sample of marking fluid was centrifuged to separate the lipid and urine fractions. The urine was subjected to five extraction cycles with methyl tert-butyl ether (Extra pure, Merck, Darmstadt, Germany). The combined extracts were concentrated under argon atmosphere to $50 \mu$ l. Aliquots were used for the determination of double-bond positions in the unsaturated constituents by dimethyl disulfide (DMDS) derivatization and GC-MS analysis (Vincenti et al. 1987).

A further urine sample $(8.87 \mathrm{ml})$ was partitioned twice with methyl tert-butyl ether, and the combined extracts were concentrated to $7 \mu \mathrm{l}$ and used for the quantitative determination of the sulfur content of the urine fraction by using elemental sulfur as the external standard.

\section{Headspace Analysis}

A sample enrichment probe (SEP; MasChrom Analisetegniek, Stellenbosch, South Africa) was used to collect volatile organic constituents from the headspace of both the unprocessed marking fluid and the urine fraction for GC and GC-MS analyses. This was done by exposing the sorptive phase of the SEP ( $28 \mathrm{mg}$ of polydimethylsiloxane rubber) 
to the headspace of, for example, a fresh sample of the urine (e.g., $46.67 \mathrm{~g}$ ) at $40^{\circ} \mathrm{C}$ for periods of 15 to $48 \mathrm{hr}$. The volatile compounds were desorbed at $220^{\circ} \mathrm{C}$ in the GC-MS injector, leaving the probe in the injector until completion of the analysis (Burger et al. 2006a).

\section{Solventless Sample Introduction of the Lipid Fraction}

The lipid phase of the marking fluid was analyzed by GC and GC-MS for its volatile organic content using the injector-internal thermal desorption technique (Biedermann et al. 2005). Aliquots of approximately 3 to $4 \mathrm{mg}$ of the lipid material were applied to the inside wall of an injector liner containing just enough silylated glass wool to prevent the lipid sample from running down the liner to the bottom of the injector. The liner was installed in the injector at $220^{\circ} \mathrm{C}$, the carrier gas was turned on, and the analysis was completed in the usual manner.

\section{Protein Analysis}

The urine fraction of the marking fluid used for protein analysis was kept frozen in an Eppendorf tube at $-80^{\circ} \mathrm{C}$ until analyzed. The protein content of the urine was estimated according to Bradford (1976) using bovine serum albumin as the standard. Prior to gel electrophoresis, proteins from lipid-free urine were concentrated, and the proteins were precipitated by adding an equal volume of $20 \%$ trichloroacetic acid to each sample. The samples were left on ice for $1 \mathrm{hr}$ and then centrifuged for $15 \mathrm{~min}$ at $4^{\circ} \mathrm{C}$ and $16,000 \times \mathrm{g}$. The supernatant was removed, the pellet was washed with $300 \mu \mathrm{l}$ of ice-cold acetone, and the suspension was centrifuged as before. The supernatant was removed, and the pellet was dried, resuspended in sodium dodecyl sulfate (SDS) polyacrylamide gel electrophoresis (PAGE) loading buffer, denatured by heating at $65^{\circ} \mathrm{C}$ for $3 \mathrm{~min}$, and loaded onto the gel.

The proteins were analyzed by denaturing PAGE (12\% SDS PAGE; Laemmli 1970) and stained with Coomassie blue according to Sambrook et al. (1989). In-gel digestion with trypsin was performed according to published methods (Shevchenko et al. 1996). The resulting partially digested peptides were separated on a Waters CapLC instrument fitted with an Atlantis dC18 column (150 mm × $100 \mu \mathrm{m}$, bead size $3 \mu \mathrm{m})$. The peptides were loaded in $2 \%$ acetonitrile/ $0.2 \%$ formic acid (solvent A), and the column was eluted by using a linear gradient from $3 \%$ of solvent B ( $98 \%$ acetonitrile/ $0.2 \%$ formic acid) to $100 \%$ of solvent B in $50 \mathrm{~min}$ at a flow rate of $1.5 \mu \mathrm{l} / \mathrm{min}$. MS/MS data of the eluting peptides were acquired from $\mathrm{m} / \mathrm{z} 400$ to 1,995 at $0.5 \mathrm{sec}$ per scan and an interscan delay of 0.1 sec by nanoelectrospray quadrupole time-of-flight MS (Waters API Q-TOF Ultima).

The resulting data were analyzed by the Matrix software. Fragments were sequence identified by database searches against publicly available mammalian databases using the Mascot search engine (Perkins et al. 1999) and confirmed using the Basic Local Alignment Search Tool (BLAST; Altschul et al. 1990). Probability-based MOWSE (Perkins et al. 1999) scores were estimated by comparing searched results against an estimated random match population and were reported as $-10 \times \log _{10}(\mathrm{P})$, with $\mathrm{P}$ as the absolute probability.

\section{Reference Compounds}

Most of the compounds required for comparison with constituents of the marking fluid were purchased from Sigma-Aldrich (Cape Town) or other chemical suppliers or were synthesized during previous research projects. The syntheses of 3-methyl-2-octanone (10), 3-methyl-2-nonanone (14), (R)-2-methylheptanoic acid, 2-methylnonanoic acid (77), 2-methyldecanoic acid (84), 2-methylundecanoic acid (89), dimethyl succinate (33), dimethyl glutarate (43), dimethyl adipate (55), N-benzylidenepentylamine (51), N-pentylurea (104), N-benzylidene-2phenylethylamine (117), and (S)-(+)-(Z)-6-dodecen-4-olide (86) are described in the Supplementary Information for this article.

\section{Results and Discussion}

In a project aimed at finding ways to count cheetah in the wild, Balme (2005) found that the animals were attracted to various perfumes, notably to Obsession for Men by Calvin Klein. To obtain territorial marking fluid for the present research, attempts were made to elicit territorial marking behavior by both the male and the female tigers, by applying different odorants to the back of the aluminum sheet that was used to collect the marking fluid. The male tiger reacted to dodecan-4-olide (85), (Z)-6-dodecen-4-olide (86), the perfume Elle (Paco Rabanne), and a synthetic mixture of the compounds that were identified early in the investigation (mixture A, Table 1 ) by spraying urine/marking fluid in the direction of the collection device, but it ignored DMDS, musk ambrette (Haarman \& Reimer, Johannesburg), and the perfume Romance (Ralph Lauren). No clear relationship between the unpleasantness of an odor (to the human nose) and the reaction of the tiger was observed. As could be expected, the tiger marked more readily just after his cage had been cleaned. 
Marking behavior was stimulated most by the synthetic mixture and by the perfume Elle. The major constituents of this perfume were not detected in the marking fluid that was collected when this perfume had been used to induce spraying behavior, proving that the collected fluid was not contaminated by the stimulant. Generally, relatively small volumes of the marking fluid were recovered, largely because the tiger usually started spraying before having fully turned his back on the collection device. Nevertheless, on two occasions, it was possible to collect 100-ml quantities of fresh fluid. In contrast to the cheetah, A. jubatus, which avoided turning its back on its reflection in the shiny aluminum surface, the tiger sprayed more readily after having inspected the shiny surface than when it was presented with a surface sprayed with green lacquer.

When left standing, the marking fluid separated into two layers: a bottom urine layer and a small upper layer of offwhite material. Centrifugation and separation of the urine from the upper layer produced a supernatant layer of clear, viscous oil. Two sample preparation and introduction techniques were employed for GC and GC-MS analyses. The first of these, a simplified version of the recently developed high-capacity SEP (Burger et al. 2006a), was used to collect the volatile constituents from the headspace of the urine fraction and to introduce the resulting sample into the injector of the GC or GC-MS instrument. The implementation of the simplified version of the SEP technique does not require modification of the injector of the GC.

In general practice and depending on the application, this technique could be more efficient than collection by solid-phase microextraction (SPME) by about two orders of magnitude (Burger and Herbert, unpublished results). The total ion chromatogram (TIC) obtained in a typical SEP analysis of the urine headspace is depicted in Fig. 1 . The prominent peaks in the lower retention time range were from alcohols, aldehydes, ketones, and fatty acids, whereas $\gamma$-lactones (alkan-4-olides) and $\delta$-lactones (alkan-5-olides) constitute some of the most prominent peaks at higher retention times. A comparison of the headspace analyses of the urine and of the whole marking fluid revealed that these liquids gave TICs with similar constituent profiles. For conventional GC and GC-MS analyses and for retention time comparison, the organic material was extracted from the urine fraction of the marking fluid with dichloromethane.

Biedermann et al. $(\underline{2005})$ recently introduced a GC sample introduction technique, described as injector-internal thermal desorption, in which volatile organic analytes present in heavy, relatively nonvolatile oils are vaporized in the injector of the gas chromatograph, cold-trapped on the column, and analyzed in the usual manner. In this technique, the heavy oil serves as a nonvolatile solvent. If samples exceeding a critical volume are injected, the oil can run down the injector liner, and some volatile material could thus be lost. This could be a problem in quantitative analysis. However, this problem can be minimized by using a small plug of silylated glass wool in the liner to support the oil at that point. By using injector-internal thermal desorption as a sample introduction technique, excellent qualitative and quantitative results were obtained in GC and GC-MS analyses of the neat lipid fraction of the marking fluid.

The territorial marking fluid of the male Bengal tiger contained a complex mixture of compounds, distributed between the aqueous (urine) and lipid phases of the fluid. The analytical problems resulting from the presence of these two phases and particularly the coelution of a large percentage of the volatile organic constituents of the marking fluid were compounded by the presence of a number of fatty acids that eluted as broad distorted peaks from the apolar capillary columns. Therefore, most of the GC and GC-MS analytical work was done on a capillary column coated with the polar phase AT-1000 (FFAP equivalent) from which the carboxylic acids eluted as sharp peaks, minimizing overlap of the carboxylic acid peaks with those of other constituents. Polar compounds (e.g., amides) eluted later than related but less polar compounds with higher molecular masses (e.g., certain N- or Calkyl-substituted amides) from this phase.

AT-1000 is also slightly acidic, resulting in some of the nitrogen-containing compounds eluting as broad, fronting peaks or, in some cases, not eluting at all. Thus, although $\mathrm{N}$-benzylidenepentylamine (51) was present in TICs obtained with this column and with column C, this compound and N-benzilidene-2-phenylethylamine (117) were identified by using the apolar column B. Samples of the marking fluid collected over a period of 3 years ranged in size from a few milliliters to $100 \mathrm{ml}$. The fluid contained varying proportions of the lipid phase, and little or no lipid was present in the smaller samples that were collected, probably because some of the viscous lipid material adhered to the collection apparatus. Analytical techniques were developed that would give a reliable picture of the qualitative and quantitative composition of the animal's marking fluid.

These techniques were then used to analyze fresh marking fluid that was free from contaminants and which contained a relatively high proportion of the lipid material to obtain a comprehensive picture of a typical sample of the fluid. Thus, crude samples were subjected to SEP-GC and -GC-MS analyses, after which the lipid material was 
separated from the urine and analyzed by GC and GC-MS by using solventless sample introduction. The organic material was exhaustively extracted from samples of the urine fraction with dichloromethane or methyl tert-butyl ether, and the extracts were analyzed by using split injection (GC and GC-MS) or on-column sample introduction (quantitative GC). The relevant qualitative and quantitative data are given in Table $\underline{1}$.

We tried to use DMDS derivatization of unsaturated compounds and GC-MS analysis of the derivatives (Vincenti et al. 1987) to determine the positions of double bonds in the unsaturated constituents of the fluid. However, the major unsaturated compounds were not quantitatively derivatized and appeared unchanged in the TIC of the reaction product, and the minor unsaturated constituents were not detected, either as the unchanged compounds or as their derivatives. Using a larger sample of the extract and a larger excess of the reagents, the derivatives of the major unsaturated compounds were still formed in very low yields. No unchanged compounds were detected in the TIC, even when a large sample $(6 \mu \mathrm{l})$ of the final product was analyzed. Fortunately, information on the positions of the double bonds in the unsaturated $y$-lactone (86) and 9-hexadecenoic acid (112) was obtained in both of these experiments.

In a repetition of the experiment with a sample of the lipid fraction, the iodine and probably also the DMDS were rapidly consumed and had to be replenished several times. Only the DMDS derivative of 9-hexadecenoic acid was detected in the product. Thus, some of the other compounds extracted from the urine or present in the lipid appear to interfere with the reaction. The double bond positional and geometric (E/Z) isomers of long-chain unsaturated compounds are not always completely resolved in capillary GC-MS analyses. Thus, although these compounds coeluted with authentic synthetic reference compounds, some of them are listed as tentatively identified in Table $\underline{1}$ if the positions of their double bonds could not be conclusively established. A larger number of compounds were identified in the urine fraction by using the SEP sample introduction technique than by conventional injection of an extract of the urine.

These differences are the result of the differences in sensitivity of these methods for compounds that differ in volatility and polarity. The SEP technique particularly facilitated the analysis of highly volatile constituents, and the profile of the volatiles obtained with this method probably gives a more accurate picture of the composition of the semiochemical message released by the tiger's marking fluid than information obtained by other methods. Regardless of the sampling technique used, GC-MS analysis showed the volatile fraction of the marking fluid to be complex, with a coelution of many constituents. Thus, although constituents were quantified by using GC data, qualitative and quantitative GC-MS data were considered to avoid incorrect assignment of peaks and to quantify overlapping or coeluting peaks. GC-MS data were also used to determine the enantiomeric composition of chiral compounds.

Because samples collected on different occasions were normally not pooled for analysis and different sample preparations, different sample introduction techniques, and different columns were employed in this research, the quantitative results reported in Table $\underline{1}$ have to be considered with some circumspection. The different ratios in which some compounds, belonging to the same compound class, were present in the urine and lipid fractions have not yet been investigated. It is nonetheless clear that the overall qualitative and quantitative picture differs substantially from the published information on the composition of the marking fluid of the tiger discussed in the introduction.

A comparison of the results of the quantitative analyses of the urine and lipid fractions of one typical sample of the marking fluid reveals that if squalene is excluded from the equation, $0.45 \mathrm{~g}$ of the lipid fraction contains about seven times the amount of volatile organic material extracted from the associated urine fraction ( $58 \mathrm{~g}$ ), illustrating the high affinity of the lipid material for the volatile organic constituents of the marking fluid, which probably enhances the lifetime of a territorial mark. Perhaps the most remarkable feature of the results reported here is the large number of lactones present in the marking fluid. Some of these lactones have relatively low vapor pressures and will persist in territorial marks, although they may not be the major active constituents of the territorial marking pheromone.

The major constituents of the headspace of the urine fraction and of the whole marking fluid were 2-heptanone (6), 2-nonanone (11), 2-undecanone (32), decanoic acid (83), (Z)-9-dodecenoic acid (96), hexadecanoic acid (111), dodecan-4-olide (85), (Z)-6-dodecen-4-olide (86), decan-5-olide (75), dodecan-5-olide (88) and, in some analyses, the nitrogen compounds N-benzylidenepentylamine (51), 2-phenylethylamine (116), and N-benzylidene-2-

phenylethylamine (117). Cadaverine and putrescine, reported as constituents of tiger urine (Brahmachary 1986), were not detected in our study, possibly because animals in the wild will occasionally eat putrid meat containing these compounds, whereas the animals used in this project were only fed fresh chicken. 2-Acetylpyrroline, 
mentioned as a constituent of tiger urine in several publications (e.g., Brahmachary 1996), also was not detected in our study. However, Brahmachary (1996) suggested that this compound could possibly be an artifact formed by a Maillard reaction during sample preparation. The two imines, N-benzylidenepentylamine (51) and N-benzylidene-2phenylethylamine (117), and N-pentylurea (104) identified in the present study might also be artifacts formed at the high temperature in the GC injector from amines and carbonyl compounds present in the tiger's marking fluid.

This possibility was not investigated, but it could be responsible for the variable quantitative results obtained for these compounds under different analytical conditions. Elemental sulfur was not found in the sample of marking fluid under discussion, but it was present in most of the analyses of SEP-collected material. In a methyl tert-butyl ether extract of the urine fraction, it was present in a concentration of $80 \mathrm{ng} / \mathrm{ml}$ of urine. Elemental sulfur eluted from column $A$ as a broad and fronting peak, extending over a retention time range of about $5 \mathrm{~min}$, at about the retention time of tetradecan-5-olide (100). Sulfur has previously been identified in the urine of the cheetah, Acynonix jubatus (Burger et al. 2006b). Except for a few minor terpenoids, the 3-methyl-2-alkanones and 2methylcarboxylic acids, 2 -ethylhexanoic acid, and a series of $\gamma$-alkylsubstituted $\gamma$-lactones and $\delta$-alkylsubstituted $\delta$ lactones were the only chiral constituents identified in the marking fluid.

No information is available on the order of elution of the enantiomers of 3-methyl-2-alkanones from chiral columns. However, it is known that (S)-2-methylheptanoic acid, for example, elutes before the (R)-enantiomer from the phase used in column C (Maas et al. 1994a). Thus, iodoform oxidation of the first-eluting enantiomer of 3methyl-2-octanone produced the second-eluting $(\mathrm{R})$-enantiomer of 2-methylheptanoic acid. The first-eluting enantiomer of the ketone therefore has $(R)$ configuration. In a repetition of this experiment with a 2:1 mixture of the ketone enantiomers, the presence of the other enantiomer of the ketone in the product served as retention time references and ruled out any possibility of incorrect interpretation of the results. By using GC-MS analysis of the SEP-collected volatiles on the enantioselective column $C$, in conjunction with cochromatography of the enriched material and racemic synthetic samples, and by using the base peak at $\mathrm{m} / \mathrm{z} 72$ in the mass spectra of these compounds for quantification, it was found that in some samples, these ketones had racemized, but that pure (R)3-methyl-2-octanone (10), (R)-3-methyl-2-nonanone (14), and (R)-3-methyl-2-decanone (26) were present in most samples (Table $\underline{2}$ ).

In GC-MS analyses that used column C, the chiral carboxylic acids 2-methylnonanoic acid (77), 2-methyldecanoic acid (84), and 2-methylundecanoic acid (89) were all found to be racemates. 2-Ethylhexanoic acid (62) eluted from column $\mathrm{E}$ as the racemate. The enantiomeric 2-methylcarboxylic acids were separated on column $\mathrm{C}$ with resolutions $(\mathrm{R} s)$ varying from 2.7 for 2-methylnonanoic acid to 2.5 for 2-methylundecanoic acid. These acids were eluted from the nonpolar enantioselective column $\mathrm{D}$ as broad and barely resolved peaks. It is unlikely that these acids were racemized during handling because they are expected to be less susceptible to racemization at $\mathrm{pH} 6.5$ than the ketones discussed above. The enantiomers of the saturated $\gamma$ - and $\delta$-lactones were resolved on column $\mathrm{D}$ with relatively high $R s$ values, ranging from 4.9 for the $C_{8}$ to 2.4 for the $C_{16} \gamma$-lactones and from 1.9 for the $C_{9}$ to 1.1 for the $\mathrm{C}_{16} \delta$-lactones.

According to Maas et al. (1994b), the (R)- $\gamma$-lactones and (S)- $\delta$-lactones under discussion elute before the respective $(S)$ - and (R)-enantiomers from this phase. The elution order of the lactone enantiomers was confirmed by comparing published data (e.g., Mosandl et al. 1989) with analyses on column D of the headspace volatiles of strawberries and raspberries, which contain the enantiomers of some of the $\gamma$ - and $\delta$-lactones present in the marking fluid. The results of the enantioselective analyses of the lactones are given in Table 2 . The enantiomeric ratios of the $C_{5}$ and $C_{6}$ lactones were not determined because they were present in insufficient concentrations. The majority of five marking fluid samples and two mixtures of, respectively, three and eight smaller samples contained the $(R)-\gamma$ - and $(S)-\delta$ - lactones (enantiomeric ratios are given in order of elution) in such high enantiomeric purities that it can be assumed that these lactones are excreted as the pure enantiomers (see Table $\underline{2}$ ).

The racemization of the chiral constituents of the marking fluid has not yet been investigated. However, some of these samples had spent $15 \mathrm{hr}$ or more at $40^{\circ} \mathrm{C}$ for the SEP collection of volatiles for qualitative and/or quantitative analyses before the enantioselective analyses were done, and it is possible that the variation in enantiomeric ratios could be explained in terms of some racemization having taken place under these conditions. The position of the double bond in the unsaturated $\gamma$-lactone, (Z)-6-dodecen-4-olide (86), was determined by MS analysis of its DMDS derivative. The (S)- and (R)-enantiomers (in the order of elution) were separated ( $R s$ 1.6) on column $D$. In contrast to the saturated $\mathrm{Y}$-lactones, the $(\mathrm{R})$-enantiomer eluted first from this column. $(\mathrm{S})-(+)-(\mathrm{Z})-6$-Dodecen-4-olide has recently been characterized in the interdigital secretion of the bontebok, Damaliscus pygargus pygargus (=D. dorcas dorcas; Burger et al., unpublished). The (R)-and (S)-enantiomers of this lactone are also present in the tarsal tuft of the black-tailed deer in a ratio of 89:11, respectively (Müller-Schwarze et al. 1978). 
In this animal, the lactone does not originate in the tarsal structure itself but is extracted from the animal's urine by the tarsal tuft (Müller-Schwarze et al. 1977). Because only one pair of captive Bengal tigers was available for this research, little time was devoted to bioassays of the identified compounds. Nevertheless, we tested the major volatile constituent of the marking fluid, dodecan-4-olide, which elicited overmarking behavior, provided that bioassays were not done more often than about once per day. A small sample of synthetic marking fluid, the composition of which is given in Table 1 (mixture B), can be made available to researchers for field tests with tigers living in the wild. The extraction of volatiles from the urine was complicated by the formation of a thin layer of semisolid material, probably denatured proteins, between the solvent and the urine.

This solid material could not be fully characterized, but positive- and negative-ion electrospray time-of-flight MS revealed the presence of scores of compounds with molecular weights ranging from 80 to 750 Da. Although our primary goal was the identification of the volatile constituents of the marking fluid, we undertook an exploratory investigation into the possibility that proteins in the marking fluid could be involved in territorial marking in the tiger. The urine fraction of a sample of marking fluid contained proteins $(0.318 \mathrm{mg} / \mathrm{ml})$ with molecular weights ranging from 16 to $180 \mathrm{kDa}$. Nine electrophoretically separable protein bands were selected for peptide analyses, from which six proteins were identified (Table $\underline{3}$ ).

Eight peptides representing $16 \%$ coverage of the serum albumin precursor of Felis silvestris catus (Miyazaki et al. $\underline{2003}$ ) were identified in the urine of P. tigris, with a high degree of sequence conservation for albumin between these species. Serum albumin is the most abundant plasma protein in mammals. Lazar et al. (2004) identified urinary albumin in the Asian elephant (Elephas maximus), where it binds the pheromone component (Z)-7dodecenyl acetate and releases it via a $\mathrm{pH}$ change. Carboxylesterase-like urinary excreted protein, also known as cauxin, is secreted in the urine of the domestic cat (F. silvestris catus), bobcat (Lynx rufus), and the lynx (L. Iynx; Miyazaki et al. 2003, 2006a), and according to Miyazaki et al. (2006a), this protein is not present in the urine of Panthera species. However, in the present study, cauxin was identified as one of the component proteins in the urine fraction of the Bengal tiger.

Six peptides representing $20 \%$ coverage of the cauxin sequence were identified. All peptides fell within the esterase-, lipase-, and coesterase-conserved domains of cauxin (covering $23 \%$ and $22 \%$ of these domains, respectively) and showed $100 \%$ homology to the published F. silvestris catus sequence (Fig. 2). Highly conserved amino acids in the substrate-binding pocket and the catalytic triad were also represented, further confirming the identity of cauxin. The function of cauxin is not known, but Miyazaki et al. (2006b) suggested that it might regulate the production of felinine (2-amino-7-hydroxy-5,5-dimethyl-4-thiaheptanoic acid), a putative pheromone precursor in the domestic cat. Carboxylesterase and $\mathrm{N}$-acylsphingosine amidohydrolase (acid ceramidase) catalyze reactions that form long-chain carboxylic acids. Acid ceramidase has previously been identified in human urine (Bernardo et al. 1995$)$. The presence of these enzymes possibly could explain the high fatty acid composition of the lipid fraction of the marking fluid.

Two immunoglobulin peptides, $(\lambda)$ - and (к)-chain, were identified. These small polypeptide subunits are components of immunoglobulins, T cell receptors, CD1 cell surface glycoproteins, secretory glycoproteins, and major histocompatibility complex class I/II molecules and have previously been identified in the urine of rodents (Hurst et al. 2005). Transthyretin is known to act as a carrier protein for various molecules, including retinol (Monaco 2000), and has been identified in rat urine (Wait et al. 2001). Healthy mammals excrete small amounts of urinary proteins, and usually proteinuria is an indicator of renal abnormality (Raila et al. 2005). However, several studies have proposed that urinary proteins are involved in chemical communication in mammals. The role of the major urinary proteins (MUPs) in the semiochemical communication of the house mouse, Mus domesticus, has been studied in great detail during the past decade (e.g., Novotny 2003 ).

For example, it was found that MUPs bind dehydro-exo-brevicomin and 2-(sec-butyl)-4,5-dihydrothiazole (Bacchini et al. 1992), which elicits male aggression in the house mouse (Novotny et al. 1985). It has also been suggested that the pattern of MUPs present in male urine may act as a type of individuality barcode that signals the identity of the owner of a particular scent mark (Beynon and Hurst 2003). On the other hand, Miyazaki et al. (2006b) suggested that the excreted MUPs of the domestic cat act as an enzyme in the synthesis of putative pheromone precursors and not as carrier proteins.

\section{Acknowledgements}

The support of the University of Stellenbosch, the Foundation for Research Development, Pretoria, and the Tygerberg Zoo, Cape Town, is gratefully acknowledged. 


\section{Figures}

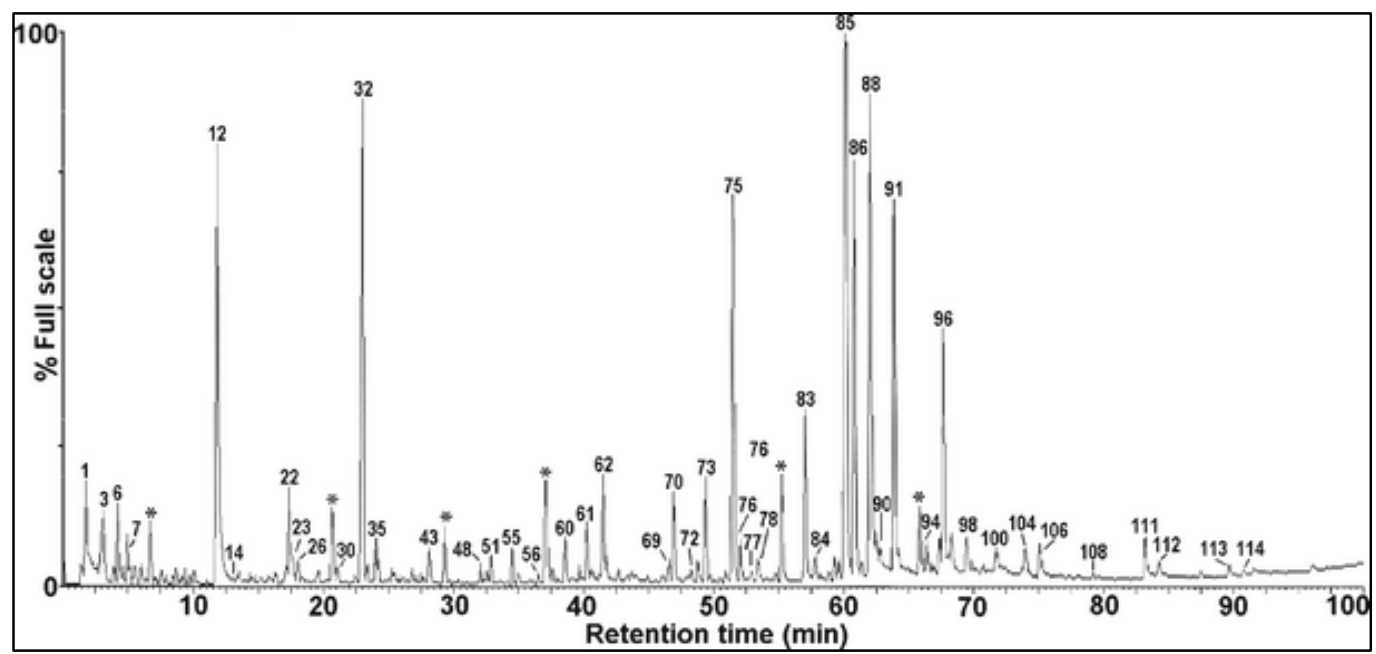

Fig. 1 TIC obtained by GC-EIMS analysis of the volatile organic compounds collected with a SEP at $40^{\circ} \mathrm{C}$ from $46.67 \mathrm{~g}$ of the urine fraction of the territorial marking fluid of the Bengal tiger on the glass capillary column $\mathrm{A}$ ( $40 \mathrm{~m} \times 0.25 \mathrm{~mm}$ i.d.) coated with $0.25 \mu \mathrm{m}$ of the polar stationary phase AT-1000 (FFAP equivalent). The column was programmed at $2^{\circ} \mathrm{C}$ from $40^{\circ} \mathrm{C}$ to $280^{\circ} \mathrm{C}$. Asterisk, Unidentified or contaminants

\begin{tabular}{|c|c|c|c|c|}
\hline & \\
\hline \multicolumn{4}{|l|}{$\begin{array}{l}\text { MSGMWVHPGRTLIWALWVLAAVIKGPAADAPVRSTRLGWVRGKQT'VLGSTVPVIMFLGIPYAAPPLC } \\
\text { RFKQPKPALPGNDFRNATSYPKLCFQDLEWLVSYQHVLKVRYPKLEASEDCLYLNIYAPAHADNGSNI } \\
\text { MVWFPGGAFKMGSASSFDGSALAAYEDVLIVTTQYRLGI FGFFDTGDEHARGNWALLDQVAALTWVR } \\
\text { EFFGGDPRSVTIFGESAGA ISVSSLILSPIANGLFHKAIMESGVAILPLLMRPPGDERKKDLQVLAR } \\
\text { CHASDSAALLQCLRAKPSEELMDISKKLTFSIPVIDDFFFPDEPVALLTQKAFNSVPSI IGVNHEC } \\
\text { LSTEFSEILGGSNRSLALYLVHTFLNIPTQYLHLVADHYFYNKHSPVEIRDSFLDLLGDVLFVVPGV } \\
\text { RYHRDAGAPVYFYEFQHPPQCLNDTRPAFVKADHSDEIRFVFGGAFLKGDIVMF BGATEEEKLLSRK }\end{array}$} & \\
\hline
\end{tabular}

Fig. 2 Protein sequence of carboxylesterase-like urinary protein (F. silvestris catus). Peptides identified in the urine of $P$. tigris are underlined 
Tables

Table 1

Compounds identified and quantified in the urine fraction, the headspace of the urine fraction, and the lipid fraction of the territorial marking fluid of the male Bengal tiger

\begin{tabular}{|c|c|c|c|c|c|c|c|}
\hline \multirow[b]{2}{*}{$\begin{array}{l}\text { Number } \\
\text { in Fig. } \\
\underline{1^{\mathrm{a}}}\end{array}$} & \multirow[b]{2}{*}{ Compound $^{\text {b }}$} & \multirow[b]{2}{*}{$\|$ Identification ${ }^{c}$} & \multicolumn{3}{|c|}{ Quantitative data } & \multirow[b]{2}{*}{$\begin{array}{l}\text { Compounds } \\
\text { in Mixture } \\
\text { A }\end{array}$} & \multirow[b]{2}{*}{$\begin{array}{l}\text { Compounds } \\
\text { in Mixture } \\
\text { B }\end{array}$} \\
\hline & & & $\begin{array}{l}\text { Collected } \\
\text { from urine } \\
\text { headspace } \\
\text { (Relative } \\
\%)^{d}\end{array}$ & $\begin{array}{l}\text { Extracted } \\
\text { from } \\
\text { urine } \\
\text { fraction } \\
(\mathrm{ng})^{\mathrm{e}}\end{array}$ & $\begin{array}{l}\text { Desorbed } \\
\text { from lipid } \\
\text { fraction } \\
(\mathrm{ng})^{\mathrm{f}}\end{array}$ & & \\
\hline 1 & Decane & $a, b$ & 15.7 & c & C & & \\
\hline 2 & Hexanal & $a, b$ & C & c & 1.5 & & \\
\hline 3 & Undecane & $a, b$ & 2.8 & $c$ & C & & \\
\hline 4 & 3-Heptanone & $a, b$ & 0.3 & 0.03 & C & & \\
\hline 5 & Heptanal & $a, b$ & c & c & 4.7 & & $\checkmark$ \\
\hline 6 & 2-Heptanone & $a, b$ & 12.9 & 2.2 & C & $\sqrt{ }$ & $\sqrt{ }$ \\
\hline 7 & 3-Methyl-1-butanol & $a, b$ & 1.7 & 3.5 & c & & $\checkmark$ \\
\hline 8 & 2-Octanone & $a, b$ & 0.3 & $c$ & C & & \\
\hline 9 & Octanal & $a, b$ & 0.6 & c & 0.9 & & \\
\hline 10 & 3-Methyl-2-octanone & $a, b$ & 0.8 & c & $c$ & & \\
\hline 11 & 2-Nonanone & $a, b$ & 77.8 & 0.3 & 1.3 & $\sqrt{ }$ & $\sqrt{ }$ \\
\hline 12 & 1-Hexanol & $a, b$ & C & C & 0.5 & & \\
\hline 13 & Nonanal & $a, b$ & 0.3 & 0.1 & 12.5 & & $\checkmark$ \\
\hline 14 & 3-Methyl-2-nonanone & $a, b$ & 0.3 & C & $\mathrm{C}$ & & \\
\hline 15 & (Z)-2-Octenal & $a, b$ & C & C & 0.6 & & \\
\hline 16 & (E)-2-Octenal & $a, b$ & c & c & 0.2 & & $\checkmark$ \\
\hline 17 & Unidentified & $a$ & c & c & 0.2 & & \\
\hline 18 & Tetradecane & $a, b$ & 0.1 & C & C & $\sqrt{ }$ & \\
\hline 19 & 1-Heptanol & $a, b$ & & 0.2 & 0.3 & & \\
\hline 20 & Acetic acid & $a, b$ & 0.7 & 0.1 & 5.4 & & \\
\hline 21 & 2-Decanone & $a, b$ & 1.6 & c & 0.2 & $\sqrt{ }$ & \\
\hline 22 & Benzaldehyde & $a, b$ & 6 & 1.4 & 0.6 & & $\checkmark$ \\
\hline 23 & Decanal & $a, d, e$ & 5.2 & C & C & & \\
\hline 24 & Unidentified & $a$ & $\mathrm{C}$ & C & 0.3 & & \\
\hline 26 & 3-Methyl-2-decanone & $a, d, e$ & 1.8 & C & 0.1 & & \\
\hline 28 & Propanoic acid & $a, b$ & C & C & 3.7 & & \\
\hline 30 & 1-Octanol & $a, b$ & 1.8 & c & 2.3 & $\checkmark$ & \\
\hline 31 & Pentan-4-olide & $a, b$ & C & 0.1 & c & & \\
\hline 32 & 2-Undecanone & $a, b$ & 65.8 & C & 2.5 & $\sqrt{ }$ & $\checkmark$ \\
\hline 33 & Dimethyl succinate & $a, b$ & 0.7 & C & C & & \\
\hline 35 & Acetophenone & $a, b$ & 3.5 & 0.1 & 0.3 & & $\checkmark$ \\
\hline 36 & Butanoic acid & $a, b$ & C & C & 0.3 & & \\
\hline 37 & Propenoic acid & $a, b$ & C & C & 0.7 & & \\
\hline 38 & 1-Methyl-2-pyrrolidone & $a, b$ & C & 0.1 & 0.8 & & \\
\hline 39 & 1-Nonanol & $a, b$ & 1.3 & C & 0.7 & & \\
\hline
\end{tabular}




\begin{tabular}{|c|c|c|c|c|c|c|c|}
\hline \multirow[b]{2}{*}{$\begin{array}{l}\text { Number } \\
\text { in Fig. } \\
\underline{1}^{\text {a }}\end{array}$} & \multirow[b]{2}{*}{ Compound ${ }^{b}$} & \multirow[b]{2}{*}{ Identification $^{c}$} & \multicolumn{3}{|c|}{ Quantitative data } & \multirow[b]{2}{*}{\begin{tabular}{|l} 
Compounds \\
in Mixture \\
A
\end{tabular}} & \multirow[b]{2}{*}{\begin{tabular}{||l} 
Compounds \\
in Mixture \\
B
\end{tabular}} \\
\hline & & & \begin{tabular}{|l} 
Collected \\
from urine \\
headspace \\
(Relative \\
$\%)^{d}$
\end{tabular} & $\begin{array}{l}\text { Extracted } \\
\text { from } \\
\text { urine } \\
\text { fraction } \\
\text { (ng) }\end{array}$ & \begin{tabular}{|l} 
Desorbed \\
from lipid \\
fraction \\
$(\mathrm{ng})^{f}$
\end{tabular} & & \\
\hline 40 & Furfuryl alcohol & $a, b$ & $c$ & $c$ & 0.2 & & \\
\hline 41 & Ethyl decanoate & $a, b$ & 0.5 & c & c & & \\
\hline 42 & Hexan-4-olide & $a, b$ & 0.5 & 0.13 & 0.1 & & \\
\hline 43 & Dimethyl glutarate & $a, b$ & 3.1 & $c$ & $c$ & & \\
\hline 45 & (Z)-2-Undecenal & $a, b$ & $c$ & $c$ & 1 & & \\
\hline 46 & But-2-enolide & $a, b$ & $c$ & $c$ & 0.7 & & \\
\hline 47 & Pentanoic acid & $a, b$ & C & $c$ & 1.1 & & $\sqrt{ }$ \\
\hline 48 & 3-Tridecanone & $a, d$ & 1.4 & c & 0.8 & & \\
\hline 49 & Pentan-5-olide & $a, b$ & 0.1 & 0.1 & 1.3 & & $\sqrt{ }$ \\
\hline 50 & Acetamide & $a, b$ & 0.2 & $c$ & 4.4 & & \\
\hline 51 & N-Benzylidenepentylamine & $a, b$ & 1.7 & c & c & & \\
\hline 52 & Formamide & $a, b$ & $c$ & $c$ & 9.3 & & \\
\hline 53 & 2-Tridecanone & $a, b$ & 1.1 & $c$ & 1.1 & $\checkmark$ & \\
\hline 54 & Propionamide & $a, b$ & c & $c$ & 0.7 & & \\
\hline 55 & Dimethyl adipate & $a, b$ & 2.2 & $c$ & c & & \\
\hline 56 & Geranylacetone & $a, b$ & 1.1 & c & 0.9 & $\checkmark$ & \\
\hline 57 & Hexanoic acid & $a, b$ & 0.2 & 0.2 & 1 & & $\checkmark$ \\
\hline 58 & Dimethylsulphone & $a, b, f$ & 0.7 & 75.6 & 3.3 & & $\checkmark$ \\
\hline 59 & Octan-4-olide & $a, b$ & 0.4 & c & c & & . \\
\hline 60 & 2-Phenylethanol & $a, b$ & 4.1 & 5.7 & C & $\checkmark$ & $\checkmark$ \\
\hline 61 & Octan-5-olide & $a, b, f$ & 6.4 & 2.8 & C & & \\
\hline 62 & 2-Ethylhexanoic acid & $a, b$ & 7.6 & c & C & & \\
\hline 63 & Heptanoic acid & a, b & |c & 0.9 & 11 & & $\| \sqrt{ }$ \\
\hline 64 & Phenol & $a, b$ & 0.4 & 0.2 & 1 & & $\checkmark$ \\
\hline 65 & Nonan-4-olide & $a, b$ & 0.7 & 0.1 & C & & \\
\hline 66 & Tridecane-2,4-dione & $a, d$ & 0.7 & $c$ & $c$ & & \\
\hline 67 & 2-Pentadecanone & $a, b$ & 0.1 & c & 3 & & $\checkmark$ \\
\hline 68 & Nonan-5-olide & $a, b$ & $c$ & 0.1 & $c$ & & \\
\hline 69 & Nerolidol & $a, b$ & 1.6 & c & 0.3 & & \\
\hline 70 & Octanoic acid & $a, b, f$ & 8.3 & 21.1 & 5.7 & & $\checkmark$ \\
\hline 71 & 1,1-Dimethylurea & $a, b$ & C & c & 50 & & \\
\hline 72 & $\begin{array}{l}\text { 2-Piperidone ( } \delta \text { - } \\
\text { valerolactam) }\end{array}$ & $a, b, f$ & 1.6 & 5.4 & 12.4 & & $\| \sqrt{ }$ \\
\hline 73 & Decan-4-olide & $a, d, e$ & 8.8 & 1 & 0.2 & & \\
\hline 74 & Hexahydrofarnesylacetone & $a, b$ & $c$ & $c$ & 1 & & \\
\hline 75 & Decan-5-olide & $a, b$ & 42 & 1.3 & 6.5 & & $\checkmark$ \\
\hline 76 & Nonanoic acid & $a, b$ & 3.1 & 0.4 & 16.5 & & $\checkmark$ \\
\hline 77 & 2-Methylnonanoic acid & $a, b$ & 0.8 & 1.1 & 0.2 & & $\checkmark$ \\
\hline 78 & 1-Tetradecanol & $a, b$ & 2.6 & $c$ & 7.5 & & $\sqrt{ }$ \\
\hline
\end{tabular}




\begin{tabular}{|c|c|c|c|c|c|c|c|}
\hline \multirow[b]{2}{*}{$\begin{array}{l}\text { Number } \\
\text { in Fig. } \\
\underline{1}^{\mathrm{a}}\end{array}$} & \multirow[b]{2}{*}{ Compound ${ }^{b}$} & \multirow[b]{2}{*}{ Identification $^{c}$} & \multicolumn{3}{|c|}{ Quantitative data } & \multirow[b]{2}{*}{\begin{tabular}{|l} 
Compounds \\
in Mixture \\
A
\end{tabular}} & \multirow[b]{2}{*}{\begin{tabular}{|l} 
Compounds \\
in Mixture \\
B
\end{tabular}} \\
\hline & & & \begin{tabular}{|l} 
Collected \\
from urine \\
headspace \\
(Relative \\
$\%)^{d}$
\end{tabular} & $\begin{array}{l}\text { Extracted } \\
\text { from } \\
\text { urine } \\
\text { fraction } \\
\text { (ng) }\end{array}$ & \begin{tabular}{|l} 
Desorbed \\
from lipid \\
fraction \\
$(\mathrm{ng})^{f}$
\end{tabular} & & \\
\hline 79 & Undecan-4-olide & $a, b$ & 0.7 & $c$ & $c$ & & \\
\hline 80 & 2-Heptadecanone & $a, b$ & c & c & 15.7 & & $\checkmark$ \\
\hline 81 & Cycloheptadecanone & $a, d$ & $c$ & $c$ & 43.2 & & \\
\hline 82 & Undecan-5-olide & $a, b$ & 0.4 & 0.05 & 0.05 & & \\
\hline 83 & Decanoic acid & $a, b$ & 15 & 22 & 28.5 & & $\checkmark$ \\
\hline 84 & 2-Methyldecanoic acid & $a, b$ & 2.1 & 3 & 5.1 & & $\checkmark$ \\
\hline 85 & Dodecan-4-olide & $a, b, f$ & 100 & 1.5 & 31.2 & $\checkmark$ & $\sqrt{ }$ \\
\hline 86 & (Z)-6-Dodecen-4-olide & $a, b, g$ & 39.9 & 0.5 & 4.8 & $\checkmark$ & $\checkmark$ \\
\hline 87 & Undecanoic acid & $a, b$ & 0.1 & 0.2 & c & & \\
\hline 88 & Dodecan-5-olide & $a, b, f$ & 60.9 & 1.9 & 27.9 & $\checkmark$ & $\checkmark$ \\
\hline 89 & 2-Methylundecanoic acid & $a, b$ & c & 2.3 & 1.4 & & $\checkmark$ \\
\hline 90 & 1-Hexadecanol & $a, b$ & 1.3 & $c$ & 58.1 & $\checkmark$ & $\checkmark$ \\
\hline 91 & (Z)-9-Hexadecen-1-ol & $a, b, d$ & $c$ & $c$ & 2.6 & & $\checkmark$ \\
\hline 92 & $\begin{array}{l}\text { Unidentified, branched } \\
\text { fatty acid }\end{array}$ & a & $\| c$ & c & 48.8 & & \\
\hline 93 & Tridecan-4-olide & $a, d, e$ & 0.2 & 0.3 & c & & \\
\hline 94 & Dodecanoic acid & $a, b$ & 2.6 & 3.7 & 15.9 & $\checkmark$ & $\checkmark$ \\
\hline 95 & Tridecan-5-olide & $a, d, e$ & 0.2 & 0.3 & 1.3 & & \\
\hline 96 & (Z)-9-Dodecenoic acid & $a, b, d, f$ & 21 & 14.2 & 63.5 & & $\sqrt{ }$ \\
\hline 97 & Phenylacetic acid & $a, b$ & 0.3 & c & 1.5 & & \\
\hline 98 & Tetradecan-4-olide & $a, d$ & 0.9 & 0.8 & 8 & & $\checkmark$ \\
\hline 99 & 1-Octadecanol & $a, b$ & c & c & 10 & & $\checkmark$ \\
\hline 100 & Tetradecan-5-olide & $a, b, e$ & 2.4 & 1.9 & 14.1 & & $\checkmark$ \\
\hline 101 & (Z)-9-Octadecen-1-ol & $a, b, d$ & c & c & 105.9 & & $\checkmark$ \\
\hline 102 & $\begin{array}{l}(\mathrm{z}, \mathrm{Z})-9,12-O c t a d e c a d i e n-1- \\
\mathrm{ol}\end{array}$ & $a, b, d$ & |c & c & $\mid 31.1$ & & $\| \checkmark$ \\
\hline 103 & 1-Methylhydantoin & $a, b, f$ & 0.7 & 7.5 & 34.9 & & $\checkmark$ \\
\hline 104 & N-Pentylurea & $a, b$ & 6.9 & c & 82.5 & & \\
\hline 105 & Urea & $a, b$ & 1.4 & $c$ & 100 & & \\
\hline 106 & Tetradecanoic acid & $a, b$ & 0.2 & 3.9 & 66.4 & $\checkmark$ & $\sqrt{ }$ \\
\hline 107 & Hexadecan-4-olide & $a, b$ & $c$ & $c$ & 1.7 & & \\
\hline 108 & Pentadecanoic acid & $a, b$ & 0.5 & 0.3 & 4 & & \\
\hline 109 & 3-Phenyl-2-propenoic acid 8 & $a, d$ & 0.1 & $c$ & 6.2 & & \\
\hline 110 & Hexadecan-5-olide & $a, d, e$ & 0.1 & c & 12.9 & & \\
\hline 111 & Hexadecanoic acid & $a, b$ & 10 & 3.8 & 99.4 & $\checkmark$ & $\checkmark$ \\
\hline 112 & (Z)-9-Hexadecenoic acid & $a, b, g$ & 3.3 & 3.1 & 60.8 & & $\checkmark$ \\
\hline 113 & Octadecanoic acid & $a, b$ & 0.9 & 1.5 & 18.5 & & $\checkmark$ \\
\hline 114 & (Z)-9-Octadecenoic acid & $a, b, d$ & 1.2 & 1.3 & 4.5 & & \\
\hline 115 & Squalene & $a, b$ & c & 3.04 & 2897 & & \\
\hline
\end{tabular}




\begin{tabular}{|c|c|c|c|c|c|c|c|}
\hline \multirow[b]{2}{*}{$\begin{array}{l}\text { Number } \\
\text { in Fig. } \\
\underline{1}^{\text {a }}\end{array}$} & \multirow[b]{2}{*}{ Compound $^{b}$} & \multirow[b]{2}{*}{ Identification $^{c}$} & \multicolumn{3}{|c|}{ Quantitative data } & \multirow[b]{2}{*}{$\begin{array}{l}\text { Compounds } \\
\text { in Mixture } \\
\text { A }\end{array}$} & \multirow[b]{2}{*}{\begin{tabular}{|l} 
Compounds \\
in Mixture \\
B
\end{tabular}} \\
\hline & & & \begin{tabular}{|l}
$\mid \begin{array}{l}\text { Collected } \\
\text { from urine } \\
\text { headspace } \\
\text { (Relative } \\
\%)^{d}\end{array}$ \\
\end{tabular} & \begin{tabular}{|l} 
Extracted \\
from \\
urine \\
fraction \\
$(\mathrm{ng})^{\mathrm{e}}$
\end{tabular} & \begin{tabular}{|l} 
Desorbed \\
from lipid \\
fraction \\
$(\mathrm{ng})^{f}$
\end{tabular} & & \\
\hline 116 & 2-Phenylethylamine & $a, d, h$ & & & & $\checkmark$ & \\
\hline 51 & $\begin{array}{l}\mathrm{N}- \\
\text { Benzylidenepentylamine } \mathrm{g}\end{array}$ & $a, b, h$ & & & & & \\
\hline 117 & $\begin{array}{l}\text { N-Benzylidene-2- } \\
\text { phenylethylamine }\end{array}$ & $a, b, h$ & & & & & \\
\hline 118 & Elemental sulfur $\left(\mathrm{S}_{8}\right)$ & $a, b, i$ & & & & & \\
\hline
\end{tabular}

${ }^{a}$ Compounds are listed in order of elution from column A (Fig. 1), although all compounds were not detected with each of the three analytical methods used.

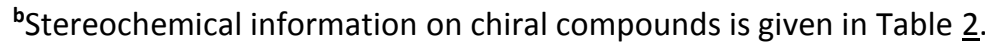

ca GC-EIMS data, b retention time comparison with synthetic compounds, c not detected or values lower than $0.03 \mathrm{ng}$, $\mathrm{d}$ tentative identification, e retention time increment comparison, $\mathrm{f} \mathrm{GC}-\mathrm{Cl}\left(\mathrm{CH}_{4}\right) \mathrm{MS}$ data, $\mathrm{g}$ double bond location by DMDS derivatization and GC-MS analysis, $h$ nitrogen-containing compounds were collected by SEP from the headspace of the urine fraction and analyzed using the apolar capillary column B, i identified in the material collected by SEP from the headspace of several samples of the marking fluid. Extraction with methyl tert-butyl ether from a urine fraction $(8.87 \mathrm{ml})$ and GC-MS analysis using sulfur as external standard gave a sulfur concentration of $80 \mathrm{ng} / \mathrm{ml}$ urine ${ }^{\mathrm{d}} \mathrm{GC}$ and GC-MS analyses of volatile organic constituents collected from the headspace of $46.67 \mathrm{~g}$ of urine for $20 \mathrm{hr}$ at $40^{\circ} \mathrm{C}$ using a SEP. Quantitative data were normalized with respect to dodecan-4-olide as $100 \%$.

${ }^{e} \mathrm{GC}$ and GC-MS analyses of the volatile organic material extracted with dichloromethane from $33.8 \mathrm{~g}$ of the urine fraction of the marking fluid. Extract concentrated to $60 \mu \mathrm{l}$ and $1 \mu \mathrm{l}$ injected on-column. The 11 homologous ketones from 2-heptanone to 2-heptadecanone were used as external standards. Quantitative data in nanograms per $33.8 \mathrm{~g}$ of urine

${ }^{\mathrm{f}} \mathrm{GC}$ and GC-MS analyses using sample introduction by injector-internal thermal desorption of $3.28 \mathrm{mg}$ of the $262.2 \mathrm{mg}$ of lipid fraction separated from the above urine fraction. Alkanones were used as external quantitative standards. Quantitative data in nanograms per $262.2 \mathrm{mg}$ of lipid material sStereochemistry not determined

Table 2

Enantiomeric composition ${ }^{\mathrm{a}}$ of chiral constituents of the marking fluid determined by GC-MS using columns C, D, and $\mathrm{E}$

\begin{tabular}{|c|c|}
\hline & npounds \\
\hline & actones $(\mathrm{R}: \mathrm{S})$ \\
\hline $\mathrm{C}_{8}$ & $72: 28$ to $58: 42\left(n=3, C^{b}\right)$ \\
\hline$C_{9}$ & $100: 0$ to $63: 37(n=4, C) ; 100: 0$ to $76: 24\left(n=4, D^{c}\right.$ \\
\hline $\mathrm{C}_{10}$ & $100: 0$ to $89: 11(n=5, C) ; 97: 3$ to $96: 4(n=6, D)$ \\
\hline $\mathrm{C}_{11}$ & 96:4 to $91: 9(n=2, C) ; 100: 0$ to $93: 7(n=5, D)$ \\
\hline $\mathrm{C}_{12}$ & $100: 0$ to $51: 49(n=6, C) ; 100: 0$ to $53: 47(n=7, D)$ \\
\hline $\mathrm{C}_{13}$ & $51: 49(n=1, C) ; 100: 0(n=2, D)$ \\
\hline $\mathrm{C}_{14}$ & $100: 0$ to $79: 21(n=6, C) ; 100: 0$ to $86: 14(n=4, D)$ \\
\hline$C_{16}$ & $60: 40$ to $51: 49(n=2, C)$ \\
\hline$(Z)-$ & 6-dodecen-4-olide (S:R) \\
\hline $\mathrm{C}_{12}$ & $95: 5$ to $64: 36(n=6, C) ; 93: 7$ to $87: 13(n=6, D)$ \\
\hline & nethylcarboxylic acids (column C) \\
\hline $\mathrm{C}_{10}$ & Racemic $(n=2)$ \\
\hline$C_{11}$ & Racemic $(n=3)$ \\
\hline
\end{tabular}




\begin{tabular}{|c|c|}
\hline & mpounds \\
\hline & Racemic $(n=3)$ \\
\hline & actones $(\mathrm{S}: \mathrm{R})$ \\
\hline & $0: 100(n=5, C) ; 0: 100$ to $25: 75(n=3, D)$ \\
\hline $\mathrm{C}_{9}$ & $0: 100(n=1, C) ; 0: 100(n=1, D)$ \\
\hline$C_{10}$ & $0: 100$ to $1: 99(n=6, C) ; 0: 100(n=6, D)$ \\
\hline$C_{11}$ & $0: 100$ to $4: 96(n=2, C) ; 0: 100(n=5, D)$ \\
\hline$C_{12}$ & $5: 95$ to $10: 90(n=6, C) ; 0: 100(n=7, D)$ \\
\hline $\mathrm{C}_{13}$ & $0: 100(n=5, D)$ \\
\hline$C_{14}$ & $0: 100$ to $8: 92(n=6, C) ; 5: 95$ to $6: 94(n=4)$ \\
\hline & $0: 100$ to $12: 88(n=2, C)$ \\
\hline & Methyl-2-alkanones (R:S) (column C) \\
\hline & $100: 0(n=4)$ \\
\hline & $100: 0$ to $47: 53(n=5)$ \\
\hline & $100: 0(n=4)$ \\
\hline & thylhexanoic acid (column E) \\
\hline & Racemic $(n=3)$ \\
\hline
\end{tabular}

aThe ratios were determined by integration of single ion plots of the base peaks of the individual compounds. The quantitative data are given in the order of elution of the enantiomers from column C or D. In some samples, one or both of the enantiomers coeluted with other constituents and could thus not be quantified, which accounts for the different numbers of samples $(\mathrm{n})$ shown in the table.

${ }^{b}$ Enantioselective column C

'Enantioselective column D

Table 3

Identification of proteins in the urine fraction of the marking fluid of the Bengal tiger

\begin{tabular}{|c|c|c|c|c|c|}
\hline $\begin{array}{l}\text { Bands from } \\
\text { 1D SDS- } \\
\text { PAGE (kDa) }\end{array}$ & MASCOT/BLAST result & $\begin{array}{l}\text { Accession } \\
\text { number }\end{array}$ & \begin{tabular}{|l|} 
Theoretical \\
molecular mass \\
(kDa)
\end{tabular} & $\begin{array}{l}\text { MASCOT } \\
\text { MOWSE } \\
\text { score }^{a}\end{array}$ & $\mid \begin{array}{l}\text { Percentage } \\
\text { coverage (number } \\
\text { peptides identified) }\end{array}$ \\
\hline 68.29 & $\begin{array}{l}\text { Carboxylesterase-like urinary } \\
\text { excreted protein (F. silvestris } \\
\text { catus) }\end{array}$ & Q81034_FELCA & 60.467 & 270 & $20(6)$ \\
\hline 56.74 & $\begin{array}{l}\text { Serum albumin precursor ( } \mathrm{F} . \\
\text { silvestris catus) }\end{array}$ & |S57632 & 68.615 & 176 & $16(8)$ \\
\hline 31.55 & $\begin{array}{l}\text { N-Acylsphingosine } \\
\text { amidohydrolase (acid } \\
\text { ceramidase)-like isoform CRA_d } \\
\text { (Homo sapiens) }\end{array}$ & EAX05759 & 43.440 & 116 & $15(4)$ \\
\hline 23.31 & $\begin{array}{l}\text { Immunoglobulin lambda chain } \\
\text { (Mus musculus) }\end{array}$ & AAA37484 & 25.387 & |72 & $7(1)$ \\
\hline 14.57 & $\begin{array}{l}\text { Immunoglobulin kappa light } \\
\text { chain (F. silvestris catus) }\end{array}$ & AAF09245 & 26.694 & 45 & $4(1)$ \\
\hline 13.61 & $\begin{array}{l}\text { Transthyretin precursor }(\mathrm{H} . \\
\text { sapiens) }\end{array}$ & |VBHU & 15.877 & $\mid 53$ & $8(1)$ \\
\hline
\end{tabular}

aProbability-based MOWSE score: Ions score is $-10 \times \log (P)$, where $P$ is the probability that the observed match is a random event. Protein scores are derived from ions scores as a nonprobabilistic basis for ranking protein hits. Individual ions scores indicating identity or extensive homology $(p<0.05)$ for each of the proteins were as follows:

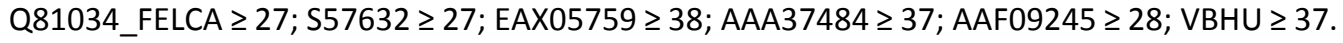




\section{References}

1. Altschul, S. F., Gish, W., Miller, W., Myers, E. W., and Lipman, D. J. 1990. Basic local alignment search tool. J. Mol. Biol. 215:403-410.

2. Bacchini, A., Gaetani, E., and Cavaggioni, A. 1992. Pheromone binding proteins of the mouse, Mus musculus. Experientia 48:419-421.

3. Balme, G. 2005. Counting cats. Afr. Geogr. 13:37-43.

4. Bernardo, K., Hurwitz, R., Zenk, T., Desnick, R. J., Ferlinz, K., Schuchman, E. H., and Sandhoff, K. 1995. Purification, characterization, and biosynthesis of human acid ceramidase. J. Biol. Chem. 270:1109811102.

5. Beynon, R. J., and Hurst, J. L. 2003. Multiple roles of major urinary proteins in the house mouse, Mus domesticus. Biochem. Soc. Trans. 31:142-146.

6. Biedermann, M., Fiselier, K., and Grob, K. 2005. Injector-internal thermal desorption from edible oils. Part 1: visual experiments on sample desorption on the liner wall. J. Sep. Sci. 28:1550-1557.

7. Bradford, M. M. 1976. A rapid and sensitive method for the quantitation of microgram quantities of protein utilizing the principle of protein-dye binding. Anal. Biochem. 72:248-254.

8. Brahmachary, R. L. 1986. Ecology and chemistry of mammalian pheromones. Endeavour, New Ser. 10:6568.

9. Brahmachary, R. L. 1996. The expanding world of 2-acetyl-1-pyrroline. Curr. Sci. 71:257-258.

10. Brahmachary, R. L., and Dutta, J. 1979. Phenylethylamine as a biochemical marker of tiger. Z. Naturforsch. 34c:632-633.

11. Brahmachary, R. L., and Dutta, J. 1987. Chemical communication in the tiger and leopard, pp. 296-302, in R. L. Tilson and U.S. Seal (eds.). Tigers of the World: The Biology, Biopolitics, Management and Conservation. Noyes, Park Ridge, NJ.

12. Brahmachary, R. L., Poddar-Sarkar, M., and Dutta, J. 1990. The aroma of rice... and tiger. Nature 344:26.

13. Burger, B. V., Marx, B., le Roux, M., and Burger, W. J. G. 2006a. Simplified analysis of organic compounds in headspace and aqueous samples by high-capacity sample enrichment probe. J. Chromatogr. A 1121:259267.

14. Burger, B. V., Petersen, W. G. B., Ewig, B. T., Neuhaus, J., Tribe, G. D., Spies, H. S. C., and Burger, W. J. G. 2008. Semiochemicals of the Scarabaeinae. VIII. Identification of the active constituents of the abdominal sex-attracting secretion of the male dung beetle, Kheper bonellii, using gas chromatography with flame ionization and electroantennographic detection in parallel. J. Chromatogr. A. 1186:254-253.

15. Burger, B. V., Visser, R., Moses, A., and le Roux, M. 2006b. Elemental sulfur identified in urine of cheetah, Acinonyx jubatus. J. Chem. Ecol. 32:1347-1352.

16. Ellerman, J., and Morrison-Scott, T. 1951. Checklist of Palaearctic and Indian Mammals, 1758 to 1946. British Museum, London (reference in G.B. Schaller. 1967. The Deer and the Tiger. University of Chicago Press, Chicago).

17. Hashimoto, Y., Eguchi, Y., and Arakawa, A. 1963. Historical observation of the anal sac and its glands of a tiger. Jpn. J. Vet. Sci. 25:29-32 (reference in K. F. Andersen and T. Vulpius. 1999. Urinary volatile constituents of the lion, Panthera leo. Chem. Senses 24:179-189).

18. Hurst, J. L., Thom, M. D., Nevison, C. M., Humphries, R. E., and Beynon, R. J. 2005. MHC odours are not required or sufficient for recognition of individual scent owners. Proc. R. Lond. Soc. B 272:715-724.

19. Laemmli, U. K. 1970. Cleavage of structural proteins during the assembly of the head of bacteriophage T4. Nature 227:680-685.

20. Lazar, J., Rasmussen, L. E., Greenwood, D. R., Bang, I. S., and Prestwich, G. D. 2004. Elephant albumin: a multipurpose pheromone shuttle. Chem. Biol. 11:1093-1100.

21. Leyhausen, P. 1960. Verhaltenstudien an Katzen, in G. B. Schaller. The Deer and the Tiger. University of Chicago Press, Chicago.

22. Leyhausen, P., and Wolff, R. 1959. Das Revier einer Hauskatze. Z. Tierpsych. 16:666-670.

23. Maas, B., Dietrich, A., and Mosandl, A. 1994a. Collection of enantiomer separation factors obtained by capillary gas chromatography on chiral stationary phases. J. High Resolut. Chrom. 17:109-115.

24. Maas, B., Dietrich, A., and Mosandl, A. 1994b. Collection of enantiomer separation factors obtained by capillary gas chromatography on chiral stationary phases. J. High Resolut. Chrom. 17:169-173.

25. Miyazaki, M., Kamiie, K., Soeta, S., Tiara, H., and Yamashita, T. 2003. Molecular cloning and characterization of a novel carboxylesterase-like protein that is physiologically present at high concentrations in the urine of domestic cats (Felis catus). Biochem. J. 370:101-110.

26. Miyazaki, M., Yamashita, T., Hosokawa, M., Tiara, H., and Suzuki, A. 2006a. Species-, sex-, and agedependent urinary excretion of cauxin, a mammalian carboxylesterase. Comp. Biochem. Physiol. Part B 145:270-277. 
27. Miyazaki, M., Yamashita, T., Suzuki, Y., Saito, Y., Soeta, S., Tiara, H., and Suzuki, A. 2006b. Major urinary protein of the domestic cat regulates the production of felinine, a putative pheromone precursor. Chem. Biol. 13:1071-1079.

28. Monaco, H. L. 2000. The transthyretin-retinol-binding protein complex. Biochim. Biophys. Acta 1482:6572.

29. Mosandl, A., Hener, U., Hagenauer-Hener, U., and Kustermann, A. 1989. Direct enantiomer separation of chiral $\gamma$-lactones from food and beverages by multidimensional gas chromatography. J. High Resolut Chromatogr. 12:532-536.

30. Müller-Schwarze, D., Ravid, U., Claesson, A., Singer, A. G., Silverstein, R. M., Müller-Schwarze, C., Volkman, N. J., Zemanek, K. F., and Butler, R. G. 1978. The deer lactone: Source, chiral properties, and responses by black-tailed deer. J. Chem. Ecol. 4:247-256.

31. Müller-Schwarze, D., Volkman, N. J., and Zemanek, K. F. 1977. Osmetrichia: specialized scent hair in blacktailed deer. J. Ultrastruct. Res. 59:223-230.

32. Novotny, M., Harvey, S., Jemiolo, B., and Alberts, J. 1985. Synthetic pheromones that promote inter-male aggression in mice. Proc. Natl. Acad. Sci. USA 82:2059-2061.

33. Novotny, M. V. 2003. Pheromones, binding proteins and receptor responses in rodents. Biochem. Soc. Trans. 31:117-122.

34. Perkins, D. N., Pappin, D. J., Creasy, D. M., and Cottrell, J. S. 1999. Probability-based protein identification by searching sequence databases using mass spectrometry data. Electrophoresis 20:3551-3567.

35. Poddar-Sarkar, M. 1996. The fixative lipid of tiger pheromone. J. Lipid Mediat. Cell Signal. 15:89-101.

36. Raila, J., Forterre, S., and Schweigert, F. J. 2005. Physiologic and pathophysiologic fundamentals of proteinuria-a review. Berl. Münch. Tierärztl. Wochenschr. 118:229-239.

37. Reiter, B., Burger, B. V., and Dry, J. 2003. Mammalian exocrine secretions. XVIII: Chemical characterization of interdigital secretion of red hartebeest, Alcelaphus buselaphus caama. J. Chem. Ecol. 29:2235-2252.

38. Sambrook, J., Fritsch, E. F., and Maniatis, T. 1989. Molecular Cloning: A Laboratory Manual. Cold Spring Harbour Laboratory Press, Cold Spring Harbor, NY.

39. Schaller, G. B. 1967. The Deer and the Tiger. University of Chicago Press, Chicago.

40. Shevchenko, A., Wilm, M., Vorm, O., and Mann, M. 1996. Mass spectrometric sequencing of proteins from silver-stained polyacrylamide gels. Anal. Chem. 68:850-858.

41. Smith, J. L. D., McDougal, C., and Miquelle, D. 1989. Scent marking in free-ranging tigers, Panthera tigris. Anim. Behav. 37:1-10.

42. Vincenti, M., Guglielmetti, G., Cassani, G., and Tonini, C. 1987. Determination of double-bond position in diunsaturated compounds by mass spectrometry of dimethyl disulfide derivatives. Anal. Chem. 59:694699.

43. Wait, R., Gianazza, E., Eberini, I., Sironi, L., Dunn, M. J., Germeiner, M., and Miller, I. 2001. Proteins of rat serum, urine, and cerebrospinal fluid: VI. Further protein identifications and interstrain comparison. Electrophoresis 22:3043-3052. 


\title{
SUPPLEMENTARY INFORMATION
}

\section{Chemical Characterization of Territorial Marking Fluid of Male Bengal Tiger, Panthera tigris}

\author{
B. V. Burger · M. Z. Viviers - J. P. I. Bekker · M. le Roux · N. Fish · W. B. Fourie · \\ G. Weibchen
}

\section{Synthesis OF Reference CoMpoundS}

3-Methyl-2-nonanone (14). Following the protocol of Smith et al. (1967), a solution of (E)-3nonen-2-one (Lancaster, Morecambe, UK) (5.0 g; $35.7 \mathrm{mmol}$ ) and t-butyl alcohol (2.64 g; $35.7 \mathrm{mmol}$ ) in dry ether $(25 \mathrm{ml})$ was added to a solution of lithium $(0.5 \mathrm{~g} ; 71.4 \mathrm{mmol})$ in liquid $\mathrm{NH}_{3}(150 \mathrm{ml})$. The reaction mixture was stirred for $30 \mathrm{~min}$, after which an excess of methyl iodide (15.2 $\mathrm{g} ; 110 \mathrm{mmol})$ in ether $(20 \mathrm{ml})$ was added over $40 \mathrm{~min}$. The $\mathrm{NH}_{3}$ was allowed to evaporate and the reaction mixture was washed with dilute $\mathrm{H}_{3} \mathrm{PO}_{4}$ and repeatedly with water to neutral $\mathrm{pH}$. The ether layer was dried over anhydrous $\mathrm{Na}_{2} \mathrm{SO}_{4}$, the drying agent was filtered off, and the solvent was removed under reduced pressure to yield a crude product that contaimed 58\% 3-methyl-2-nonanone. Purification by preparative GC on column F yielded a sample of pure ketone 14. MS (70 eV): $156\left(\mathrm{M}^{+}, 1\right), 85(7), 72(88), 71(17), 57$ (34), 55 (10), 43 (100), 41 (28), 39 (9). ${ }^{1} \mathrm{H}$ NMR (CDCl, $\left.400 \mathrm{MHz}\right): \delta=0.88$ (t, 3H, J = 6.8, H-9), 1.07 (d, 3H, J = 6.8, H-10), 1.27 (b, 8H, H-5 to H-8), $1.34(\mathrm{~m}, 1 \mathrm{H}, \mathrm{H}-4 \mathrm{a}), 1.64(\mathrm{~m}, 1 \mathrm{H}, \mathrm{H}-4 \mathrm{~b}), 2.13(\mathrm{~s}, 3 \mathrm{H}, \mathrm{H}-1), 2.49(\mathrm{~m}, 1 \mathrm{H}$, $\mathrm{H}-10) .{ }^{13} \mathrm{C} \mathrm{NMR}\left(\mathrm{CDCl}_{3}, 100 \mathrm{MHz}\right): \delta=14.08$ (q, C-9), 16.19 (q, C-10), 22.62 (t, C-8), 27.21 (t, C-5), 27.99 (q, C-1), 29.35 (t, C-6), 31.71 (t, C-7), 32.96 (t, C-4), 47.26 (d, C-3), 213.05 (s, C-2).

3-Methyl-2-octanone (10) was prepared from (E)-3-octen-2-one (Lancaster) as described above. Instead of $t$-butyl alcohol, water was used as proton donor. The crude product contained $51 \%$ of 3methyl-2-octanone (10), which was purified by preparative GC as described above. MS (70 eV): $142\left(\mathrm{M}^{+}\right.$, 2), 99 (2), 85 (8), 72 (91), 57 (65), 55 (9), 43 (100), 41 (39), 39 (13). ${ }^{1} \mathrm{H}$ NMR (CDCl, $\left.400 \mathrm{MHz}\right): \delta=0.88(\mathrm{t}$, $3 \mathrm{H}, J=6.8 \mathrm{~Hz}, \mathrm{H}-8), 1.07$ (d, 3H, J=6.8 Hz, H-9), 1.26 (b, 6H, H-5 to H-7), 1.34 (m, 1H, H-4a), 1.64 (m, $1 \mathrm{H}$, $\mathrm{H}-4 \mathrm{~b}), 2.13$ (s, 3H, H-1), $2.5(\mathrm{~m}, 1 \mathrm{H}, \mathrm{H}-3) .{ }^{13} \mathrm{C} \mathrm{NMR}\left(\mathrm{CDCl}_{3}, 100 \mathrm{MHz}\right): \delta=14.04$ (q, C-8), 16.19 (q, C-9), 22.53 (t, C-7), 26.91 (t, C-5), 27.98 (q, C-1), 31.88 (t, C-6), 32.92 (t, C-4), 47.25 (d, C-3), 213.03 (s, C-2).

(R)-2-Methylheptanoic acid. Preparative GC separation of the enantiomers of synthetic 3methyl-2-octanone (10) on enantioselective column $\mathrm{C}$ yielded a pure sample of the enantiomer that was eluted from this column with the shorter retention time. As described below, it was converted by 
iodoform oxidation to $(R)$-2-methylheptanoic acid, which eluted with the longer retention time from column C.

An enantio-enriched sample ( $250 \mu \mathrm{g})$ of 3-methyl-2-octanone containing 66\% (GC-MS) of the enantiomer with the shorter retention time on column $\mathrm{C}$ was isolated from the racemate by preparative GC on this column. A cold solution of freshly prepared sodium hypobromite (15 $\mu$ l) (Auburn et al., 1985) was added to a stirred solution of this sample in 1,4-dioxane $(15 \mu \mathrm{l})$ and water $(7.5 \mu \mathrm{l})$ in a 1-ml Reacti-Vial at $0^{\circ} \mathrm{C}$. The mixture was stirred at $0^{\circ} \mathrm{C}$ for $3 \mathrm{hr}$ and then quenched by addition of a drop of aqueous sodium bisulfite (10\%). The solvent was blown off in a slow stream of nitrogen, then the residue was dissolved in water $(50 \mu \mathrm{l})$ and acidified $(\mathrm{pH} 1)$ with $\mathrm{H}_{2} \mathrm{SO}_{4}(1.5 \mathrm{M})$. The organic material was extracted twice with dichloromethane $(50 \mu l)$ and the extract was washed with water, dried over anhydrous magnesium sulfate, and analyzed by chiral GC and GC-MS using capillary column C. The product, 2methylheptanoic acid, contained $66 \%$ of the $(R)$-enantiomer, which eluted with the longer retention time from column C. MS (70 eV): 144 ( $\left.\mathrm{M}^{+}, 0.2\right), 101$ (10), 87 (23), 74 (100), 73 (18), 69 (6), 57 (17), 55 (11), 45 (8), 43 (17), 41 (22), 39 (8), 29 (7), 27 (8).

\section{2-Methylnonanoic acid (77), 2-methyldecanoic acid (84), and 2-methylundecanoic acid (89) were} synthesized from diethyl methylmalonate and the appropriate bromoalkanes (Furniss et al., 1989). A typical procedure follows. Diethyl methylmalonate $(6.42 \mathrm{~g} ; 100 \mathrm{mmol})$ was added dropwise to a stirred solution of sodium ethoxide $(36.9 \mathrm{mmol})$ in absolute ethanol $(5 \mathrm{ml})$. 1-Bromoheptane $(6.60 \mathrm{~g} ; 36.9 \mathrm{mmol})$ then was added over a period of $1 \mathrm{hr}$, and the mixture was refluxed for several hours until it reached a neutral $\mathrm{pH}$. The resulting product, containing diethyl methyloctylmalonate, was slowly added to a hot solution of $\mathrm{KOH}(7.95 \mathrm{~g} ; 142 \mathrm{mmol})$ in water $(16 \mathrm{ml})$ and the reaction mixture was refluxed for $3 \mathrm{hr}$ to hydrolyze the ester. After extraction of any unsaponified material with chloroform, the reaction mixture was acidified with $\mathrm{H}_{3} \mathrm{PO}_{4}$ and refluxed for $4 \mathrm{hr}$ to decarboxylate the methyloctylmalonic acid. The reaction mixture was cooled and the product extracted with ether. The extract was washed to neutral $\mathrm{pH}$ with water and dried over anhydrous $\mathrm{Na}_{2} \mathrm{SO}_{4}$. Filtration and solvent concentration yielded a crystalline product containing the target compound as well as some methyloctylmalonic acid that had not undergone decarboxylation. Heating this material under reduced pressure $(20 \mathrm{~mm} \mathrm{Hg})$ for $2 \mathrm{hr}$ at $150^{\circ} \mathrm{C}$ completed the decarboxylation to yield 2-methylnonanoic acid $(77)(4.64 \mathrm{~g})$ in a purity of $97 \%$. MS (70 eV): $172\left(\mathrm{M}^{+}\right.$, 3), 143 (8), 129 (20), 115 (13), 101 (8), 87 (73), 74 (100), 69 (25), 57 (30), 55 (44), 45 (22), 43 (58), 41 (67), 39 (24), 29 (35). ${ }^{1} \mathrm{H} \mathrm{NMR}\left(\mathrm{CDCl}_{3}, 300 \mathrm{MHz}\right): \delta=0.88$ (t, 3H, J = 6.9, H-9), 1.17 (d, 3H, J = 7.0, H-10), 1.28 (b, $10 \mathrm{H}, \mathrm{H}-4$ to $\mathrm{H}-8), 1.45(\mathrm{~m}, 1 \mathrm{H}, \mathrm{H}-3 \mathrm{a}), 1.68(\mathrm{~m}, 1 \mathrm{H}, \mathrm{H}-3 \mathrm{~b}), 2.45$ (m, 1H, H-2). ${ }^{13} \mathrm{C} \mathrm{NMR}\left(\mathrm{CDCl}_{3}, 75 \mathrm{MHz}\right): \delta=$ 14.09 ( $q, C-9), 16.82$ ( $q, C-10), 22.67$ (t, C-8), 27.17 (t, C-4), 29.16 and 29.5 (t, C-5 and t, C-6), 31.85 (t, C-7) 33.55 (t, C-3), 39.45 (d, C-2), 183.75 (s, C-1).

2-Methyldecanoic acid (84) was synthesized as described above from diethyl methylmalonate and 1-bromooctane. MS (70 eV): $186\left(\mathrm{M}^{+}, 4\right), 157$ (2), 143 (20), 129 (27), 115 (5), 101 (8), 87 (80), 74 
(100), 69 (19), 7 (31), 55 (50), 45 (15), 43 (67), 41 (75), 39 (27), 29 (43). $\left.{ }^{1} \mathrm{H} \mathrm{NMR} \mathrm{(CDCl} 3,300 \mathrm{MHz}\right): \delta=0.88$ $(\mathrm{t}, 3 \mathrm{H}, J=6.8, \mathrm{H}-10), 1.18(\mathrm{~d}, 3 \mathrm{H}, J=7.0, \mathrm{H}-11), 1.27(\mathrm{~b}, 12 \mathrm{H}, \mathrm{H}-4$ to $\mathrm{H}-9), 1.45(\mathrm{~m}, 1 \mathrm{H}, \mathrm{H}-3 \mathrm{a}), 1.68(\mathrm{~m}, 1 \mathrm{H}$, $\mathrm{H}-3 \mathrm{~b}), 2.45$ ( $\mathrm{m}, 1 \mathrm{H}, \mathrm{H}-2) .{ }^{13} \mathrm{C} \mathrm{NMR}\left(\mathrm{CDCl}_{3}, 75 \mathrm{MHz}\right): \delta=14.11$ (q, C-10), 16.82 (q, C-11), 22.69 (t, C-9), 27.17 (t, C-4), 29.29, 29.45, 29.53 (t, C-5 to C-7), 31.89 (t, C-8) 33.57 (t, C-3), 39.45 (d, C-2), 183.7 (s, C-1).

2-Methylundecanoic acid (89) was prepared from diethyl methylmalonate and 1-bromononane. MS (70 eV): 200 ( $\left.\mathrm{M}^{+}, 5\right), 171$ (2), 157 (10), 143 (32), 129 (18), 115 (5), 101 (10), 87 (84), 74 (100), 69 (23), 57 (33), 55 (56), 45 (20), $43(66), 41$ (70), 39 (21), 29(38). ). ${ }^{1} \mathrm{H}$ NMR (CDCl, $\left.300 \mathrm{MHz}\right): \delta=0.88(\mathrm{t}, 3 \mathrm{H}, J=$ 6.8, H-11), 1.17 (d, 3H, J = 6.8, H-12), 1.26 (b, 14H, H-4 to H-10), 1.45 (m, 1H, H-3a), 1.69 (m, 1H, H-3b), $2.45(\mathrm{~m}, 1 \mathrm{H}, \mathrm{H}-2) .{ }^{13} \mathrm{C} \mathrm{NMR}\left(\mathrm{CDCl}_{3}, 75 \mathrm{MHz}\right): \delta=14.13$ (q, C-11), 16.82 (q, C-12), 22.7 (t, C-10), 27.17 (t, C4), 29.34, 29.5, 29.53, 29.58 (t, C-5 to C-8), 31.91 (t, C-9) 33.57 (C-3), 39.46 (d, C-2), 183.69 (s, C-1).

Dimethyl succinate (33), dimethyl glutarate (43), and dimethyl adipate (55) were synthesized by acid-catalyzed esterification of the corresponding dicarboxylic acids with methanol (Furniss, 1989). The mass spectra of the products were in agreement with mass spectral data in the NBS and NIST mass spectra libraries

$N$-Benzylidenepentylamine (51) (For structures see Figure 1) was synthesized by the condensation of benzaldehyde with pentylamine according to the protocol of Tietze and Eicher (1981). A vigorously stirred suspension of anhydrous sodium sulfate $(2.4 \mathrm{~g})$ in a mixture of benzaldehyde $(1.0 \mathrm{~g}, 0.01$ $\mathrm{mol}$ ) and benzene ( $3.2 \mathrm{ml})$ was treated dropwise with pentylamine $(0.9 \mathrm{~g}, 0.01 \mathrm{~mol})$ over $15 \mathrm{~min}$, and the mixture was stirred for a further $12 \mathrm{hr}$. The sodium sulfate was filtered off and washed repeatedly with benzene. Removal of the solvent under reduced pressure and distillation of the residue (bp 59-60 ${ }^{\circ} \mathrm{C}, 0.04$ $\mathrm{mm} \mathrm{Hg}$ ) gave $N$-benzylidenepentylamine (51) (1.0 g, 57\%). MS (70eV): 209 ( $\left.\mathrm{M}^{+}, 5\right), 208$ (28), 132 (9), 118 (100), 103 (5), 91 (87), 77 (9), 65 (10), 51 (6), 39 (7). $\left.{ }^{1} \mathrm{H} \mathrm{NMR} \mathrm{(CDCl}, 300 \mathrm{MHz}\right): \delta=0.84(\mathrm{t}, 3 \mathrm{H}, J=7 \mathrm{~Hz}, \mathrm{H}-$ 5), $1.27(\mathrm{~m}, 4 \mathrm{H}, \mathrm{H}-3$ and $\mathrm{H}-4), 1.63(\mathrm{~m}, 2 \mathrm{H}, \mathrm{H}-2), 3.52\left(\mathrm{dt}, 2 \mathrm{H},{ }^{3} \mathrm{~J}=7 \mathrm{~Hz},{ }^{4} \mathrm{~J}=1.4 \mathrm{~Hz}, \mathrm{H}-1\right), 7.3(\mathrm{~m}, 3 \mathrm{H}, \mathrm{Ar})$, $7.64(\mathrm{~m}, 2 \mathrm{H}, \mathrm{Ar}), 8.17$ (t, $1 \mathrm{H},{ }^{4} \mathrm{~J}=1.4 \mathrm{~Hz}, \mathrm{~N}=\mathrm{C}-\mathrm{H}-$ ). ${ }^{13} \mathrm{C} \mathrm{NMR}\left(\mathrm{CDCl}_{3}, 75 \mathrm{MHz}\right.$ ): $\delta=13.98$ (q, C-5), 22.44 (t, C-4), $29.47(t, C-3), 30.54$ (t, C-2), 61.68 (t, C-1), 127.90 (d, C-2' and C-6'), 128.19 (d, C-3' and C-5'), 128.43 (d, C$\left.4^{\prime}\right), 136.29$ (s, C-1'), 160.5 (d, C-7', N=ㅌ- - ). (Numbering as shown in Fig. 1.)

N-Pentylurea (104). Pentylammonium chloride (6.18 g, $0.057 \mathrm{~mol})$ and urea (13.77 g, $0.229 \mathrm{~mol})$ were refluxed in a mixture of glacial acetic acid and dilute hydrochloric acid (Kurzer, 1963). On cooling, the target compound 104 precipitated as fine colorless crystals (5.33 g, 72\%, purity $94 \%$ by GC-MS), m.p. 92-96 ${ }^{\circ} \mathrm{C} . \mathrm{MS}(70 \mathrm{eV}): 130\left(\mathrm{M}^{+}, 4\right), 101$ (6), 87 (5), 74 (14), 73 (31), 61 (4), 55 (3), 44 (22), 41 (12), 30 (100); $\left.{ }^{1} \mathrm{H} \mathrm{NMR}_{(\mathrm{CDCl}}, 300 \mathrm{MHz}\right): \delta=0.89\left(\mathrm{t}, 3 \mathrm{H}, J=7 \mathrm{~Hz}, \mathrm{H}-5^{\prime}\right), 1.31\left(\mathrm{~m}, 4 \mathrm{H}, \mathrm{H}-3^{\prime}\right.$ and $\left.\mathrm{H}-4^{\prime}\right), 1.5\left(\mathrm{~m}, 2 \mathrm{H}, \mathrm{H}-2^{\prime}\right), 3.13$ $\left(\mathrm{m}, 2 \mathrm{H}, J=6.8 \mathrm{~Hz}, J=5.9 \mathrm{~Hz}, \mathrm{H}-1^{\prime}\right), 4.53\left(\mathrm{br}, 2 \mathrm{H}, \mathrm{NH}_{2}\right), 4.83(\mathrm{br}, 1 \mathrm{H}, \mathrm{N} \underline{\mathrm{H}}) .{ }^{13} \mathrm{C} \mathrm{NMR}\left(\mathrm{CDCl}_{3}, 75 \mathrm{MHz}\right): \delta=$ 14.02 (q, C-5), 22.4 (t, C-4), 29.03 (t, C-3), 29.78 (t, C-2), 40.81 (t, C-1), 158.94 (s, $\underline{\mathrm{C}=}$ ) $).$

$\mathrm{N}$-Benzylidene-2-phenylethylamine (117). Condensation of benzaldehyde (11.11 g, $0.1 \mathrm{~mol})$ with 2-phenylethylamine (14 g, $0.12 \mathrm{~mol}$ ) according to Tietze and Eicher (1981), yielded N-benzylidene-2- 
phenylethylamine (117) (9.2 g, 44\%). MS (70eV): 174 (5), 160 (34), 146 (7), 132 (42), 118 (68), 104 (41), 98 (9), 91 (100), 89 (13), 77 (18), 65 (13), 51 (13), 43 (12), 41 (28), 39 (17), 29 (10), 27 (22); ${ }^{1} \mathrm{H} \mathrm{NMR} \mathrm{(CDCl} 3$, $300 \mathrm{MHz}): \delta=2.94\left(\mathrm{t}, 2 \mathrm{H},{ }^{3} \mathrm{~J}=7 \mathrm{~Hz}, \mathrm{H}-2\right), 3.75\left(\mathrm{td}, 2 \mathrm{H},{ }^{3} \mathrm{~J}=7 \mathrm{~Hz},{ }^{4} \mathrm{~J}=c a .1 .4 \mathrm{~Hz}, \mathrm{H}-1\right), 7.1$ to $7.3(\mathrm{~m}, 8 \mathrm{H}, \mathrm{Ar})$, $7.64\left(\mathrm{~m}, 2 \mathrm{H}, \mathrm{H}-2^{\prime \prime}\right.$ and H-6"), 7.97 (br t, $\left.{ }^{4} \mathrm{~J}=\mathrm{ca} .1 .4 \mathrm{~Hz}, \mathrm{~N}=\mathrm{C} \underline{\mathrm{H}}-\mathrm{-}\right) .{ }^{13} \mathrm{C} \mathrm{NMR}\left(\mathrm{CDCl}_{3}, 75 \mathrm{MHz}\right): \delta=37.08$ (t. C-2), 62.59 (t, C-1), 125.67 (d, C-2' and C-6'), 135.81 (s, C-1'), 139.49 (s, C-1'), 127.63 (d, Ar), 127.90 (d, Ar), 128.09 (d, Ar), 128.59 (d, Ar), 130.07 (d, Ar), 160.77 (d, N=ㅡH-). (Numbering as shown in Fig. 1.)

(S)-(+)-(Z)-6-Dodecen-4-olide (86) was prepared as outlined in Fig. 1 according to Ravid et al. (1978). A solution of (S)-(+)- $\gamma$-carboxyl- $\gamma$-butyrolactone (119) (Fluka, Buchs, Switzerland) (17.9 g, 138 $\mathrm{mmol})$ in dry THF $(100 \mathrm{ml})$ was treated under argon with a solution of borane-dimethyl sulfide complex (Sigma-Aldrich, Cape Town) (158 ml, 158 mmol) over 3 hr (Cohen et al., 1979). The mixture was stirred overnight and then carefully diluted with $\mathrm{MeOH}$. Concentration and distillation $\left(110^{\circ} \mathrm{C}, 1 \mathrm{~mm} \mathrm{Hg}\right)$ yielded (S)-(+)- $\gamma$-hydroxymethyl- $\gamma$-butyrolactone $(120)(14.3 \mathrm{~g}, 89 \%) .[\alpha]_{D}^{20}=+50.1^{\circ}$ (c $\left.=1.03, \mathrm{CHCl}_{3}\right) . \mathrm{MS}(70 \mathrm{eV})$ : $116\left(\mathrm{M}^{+}, 1\right), 98(1), 86(11), 85$ (100), 57 (15), 56 (5), 55 (5), 44 (4), 43 (6), 42 (8), 41 (5), 39 (8). ${ }^{1} \mathrm{H}$ NMR $\left(\mathrm{CDCl}_{3}, 400 \mathrm{MHz}\right): \delta$ = 2.09-2.20 (m, 1H, H-3a), 2.21-2.32 (m, 1H, H-3b), 2.48-2.67 (m, 2H, H-2), 3.64 (dd, $\left.1 \mathrm{H},{ }^{2} \mathrm{~J}=4.7 \mathrm{~Hz},{ }^{3} \mathrm{~J}=12.5 \mathrm{~Hz}, \mathrm{H}-5 \mathrm{a}\right), 3.89$ (dd, $\left.1 \mathrm{H},{ }^{2} \mathrm{~J}=2.8 \mathrm{~Hz},{ }^{3} \mathrm{~J}=12.5 \mathrm{~Hz}, \mathrm{H}-5 \mathrm{~b}\right), 4.62(\mathrm{~m}, 1 \mathrm{H}, \mathrm{H}-4) .{ }^{13} \mathrm{C} N M R$ $\left(\mathrm{CDCl}_{3}, 101 \mathrm{MHz}\right): \delta=23.58(\mathrm{t}, \mathrm{C}-3), 29.09$ (t, C-2), 64.54 (t, C-5), 81.21 (d, C-4). (Numbering as shown in Fig. 1.)

p-Toluenesulfonyl chloride (35 g, $183 \mathrm{mmol}$ ) was added to a solution of $(S)-(+)-\gamma$-hydroxymethyl$\mathrm{Y}$-butyrolactone $(\mathbf{1 2 0})(14.3 \mathrm{~g}, 123 \mathrm{mmol})$ in dry pyridine $(130 \mathrm{ml})$ at $0^{\circ} \mathrm{C}$ and the reaction mixture was stirred overnight. The resulting mixture was poured into saturated, ice-cold aqueous $\mathrm{NaHCO}_{3}(200 \mathrm{ml})$ and the organic material was extracted with ethyl acetate $(2 \times 200 \mathrm{ml})$. The combined organic extracts were washed with saturated $\mathrm{NaHCO}_{3}(50 \mathrm{ml})$ and brine $(50 \mathrm{ml})$, dried over anhydrous $\mathrm{MgSO}_{4}$, filtered, and concentrated to yield pure $(S)-(+)-\gamma$-tosyloxymethyl- - -butyrolactone (121) (30.0 g, $90 \%$ \%). $[\alpha]_{D}^{20}=+45.2^{\circ}$ (c= 1.13, $\left.\mathrm{CHCl}_{3}\right) . \mathrm{MS}(70 \mathrm{eV}): 270\left(\mathrm{M}^{+}, 3\right), 207$ (2), 206 (16), 155 (10), 107 (8), 99 (10), 98 (2), 92 (4), 91 (36), 89 (5), 86 (4), 85 (100), 77 (2), 65 (17), 63 (4), 57 (5), $56(2), 55$ (3), $51(2), 43(4), 41(5), 39(10) .{ }^{1} \mathrm{H}$ $\operatorname{NMR}\left(\mathrm{CDCl}_{3}, 400 \mathrm{MHz}\right): \delta=2.09-2.19(\mathrm{~m}, 1 \mathrm{H}, \mathrm{H}-3 \mathrm{a}), 2.3-2.4(\mathrm{~m}, 1 \mathrm{H}, \mathrm{H}-3 \mathrm{~b}), 2.46$ (s, 3H, Me-Ar), 2.47-2.65 $(\mathrm{m}, 2 \mathrm{H}, \mathrm{H}-2), 4.16\left(\mathrm{dd}, 2 \mathrm{H},{ }^{2} \mathrm{~J}=3.5 \mathrm{~Hz},{ }^{3} \mathrm{~J}=11 \mathrm{~Hz}, \mathrm{H}-5\right), 4.68(\mathrm{~m}, 1 \mathrm{H}, \mathrm{H}-4), 7.37\left(\mathrm{~d}, 2 \mathrm{H},{ }^{3} \mathrm{~J}=8.2 \mathrm{~Hz}, \mathrm{H}-3-\mathrm{Ar}\right)$, $7.79\left(\mathrm{~d}, 2 \mathrm{H},{ }^{3} \mathrm{~J}=8.2 \mathrm{~Hz}, \mathrm{H}-2-\mathrm{Ar}\right) .{ }^{13} \mathrm{C} \mathrm{NMR}\left(\mathrm{CDCl}_{3}, 101 \mathrm{MHz}\right): \delta=21.83$ (d, Me-Ar), 23.72 (t, C-3), 28.01 (t, C2), 70.04 (t, C-5), 76.52 (d, C-4), 128.12 (d, C-2-Ar), 130.2 (d, C-3-Ar), 132.5 (s, C-1-Ar), 145.61 (s, C-4-Ar), $177.11(\mathrm{~s}, \mathrm{C}-1)$. 


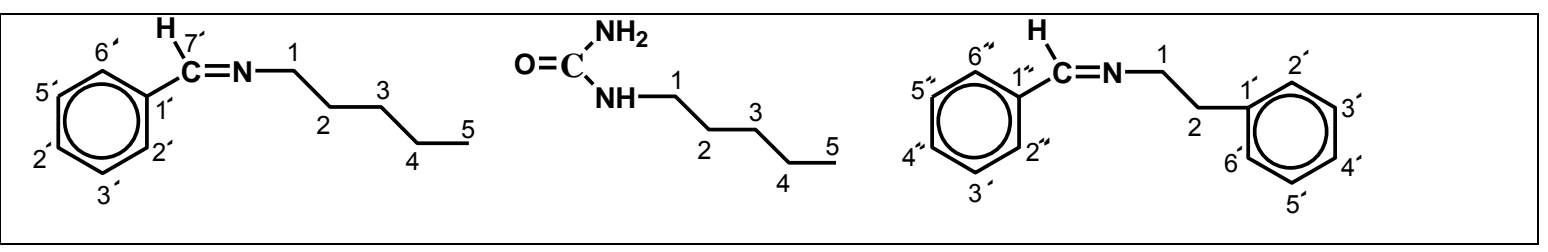

51

104

117

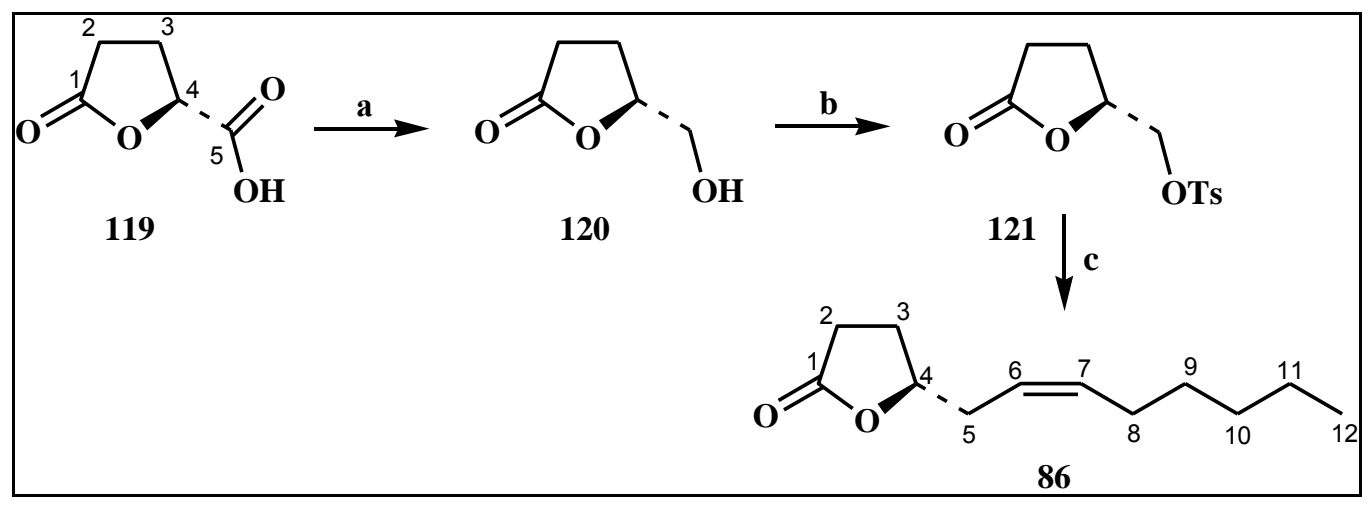

a: $\mathrm{BH} 3 \cdot \mathrm{S}\left(\mathrm{CH}_{3}\right)_{2}$, THF; b: TsC1, Pyridine; c: $n$-BuLi, (Z)-1-lodoheptene, $\mathrm{Cul}, \mathrm{Et}_{2} \mathrm{O}$

Fig. 1. Structures of compounds $51,104,117$, and the reaction scheme for the preparation of $(S)-(+)-(Z)-6-$ dodecen-4-olide (86).

A solution of (Z)-1-iodo-1-heptene $(2.84 \mathrm{~g}, 12.6 \mathrm{mmol})$ in dry diethyl ether $(25 \mathrm{ml})$ was cooled to $-78^{\circ} \mathrm{C}$ and treated dropwise with a solution of $n$-BuLi in hexane $(8 \mathrm{ml} 1.6 \mathrm{M}, 12.8 \mathrm{mmol})$ under argon. The mixture was stirred for $45 \mathrm{~min}$ at -70 to $-80^{\circ} \mathrm{C}$, then added to a suspension of copper $(\mathrm{I})$ iodide $(1.7 \mathrm{~g}, 8.27$ $\mathrm{mmol}$ ) in dry diethyl ether. This mixture was stirred at -30 to $-60^{\circ} \mathrm{C}$ for $60 \mathrm{~min}$ and then cooled to $-70^{\circ} \mathrm{C}$. A solution of $(S)-(+)-\gamma$-tosyloxymethyl- - -butyrolactone (121) $(1.63 \mathrm{~g}, 6.03 \mathrm{mmol})$ in dry dichloromethane $(120 \mathrm{ml})$ was injected slowly into the reaction mixture, which was then stirred for a further $8 \mathrm{hr}$ at -30 to $-50^{\circ} \mathrm{C}$, and poured into ice-cold saturated $\mathrm{NH}_{4} \mathrm{Cl}$. After filtration through Celite the organic phase was separated from the aqueous phase. The organic product was extracted with ethyl acetate $(4 \times 50 \mathrm{ml})$ and the combined organic phases were washed with saturated $\mathrm{NH}_{4} \mathrm{Cl}(100 \mathrm{ml})$, dried over anhydrous $\mathrm{MgSO}_{4}$, filtered, and concentrated. The product was dissolved in ethyl acetate $(100 \mathrm{ml})$ and the saponifiable material extracted with $\mathrm{NaOH}$ solution $(10 \mathrm{M}, 5 \times 40 \mathrm{ml})$. The aqueous phase was acidified with $2.5 \mathrm{M} \mathrm{HCl}$ to $\mathrm{pH} 4$, and the organic product extracted with ethyl acetate $(5 \times 50 \mathrm{ml})$. The combined extracts were dried and concentrated to yield (S)-(+)-(Z)-6-dodecen-4-olide (86) (130 mg, 11\%). $[\alpha]_{D}^{20}=+14.8^{\circ}(\mathrm{c}=1.1$, MeOH). MS (70eV): $196\left(\mathrm{M}^{+}, 3\right), 136$ (4), 96 (12), 95 (3), 94 (2), 93 (3), 86 (7), 85 (100), 82 (3), 81 (7), 80 (4), 79 (5), 77 (2), 69 (4), 68 (2), 67 (7), 57 (9), 56 (3), 55 (10), 54 (7), 53 (4), 43 (3), 42 (2), 41 (18), 39 (10). 
${ }^{1} \mathrm{H} \mathrm{NMR}\left(\mathrm{CDCl}_{3}, 400 \mathrm{MHz}\right): \delta=0.89\left(\mathrm{t}, 3 \mathrm{H},{ }^{3} \mathrm{~J}=6.9 \mathrm{~Hz}, \mathrm{H}-12\right), 1.23-1.40(\mathrm{~m}, 6 \mathrm{H}, \mathrm{H}-9$ to $\mathrm{H}-11), 1.85-1.95(\mathrm{~m}$, $1 \mathrm{H}, \mathrm{H}-3 \mathrm{a}), 2.03$ (q, 2H, $\left.{ }^{3} \mathrm{~J}=7.2 \mathrm{~Hz}, \mathrm{H}-8\right), 2.25-2.34$ (m, 1H, H-3b), 2.36-2.44 (m, 1H, H-5a), 2.46-2.52 (m, $1 \mathrm{H}, \mathrm{H}-5 \mathrm{~b}$ ), 2.5-2.57 (m, 2H, H-2), 4.52 (quin, $\left.1 \mathrm{H},{ }^{3} \mathrm{~J}=6.6 \mathrm{~Hz}, \mathrm{H}-4\right), 5.31-5.38(\mathrm{~m}, 1 \mathrm{H}, \mathrm{H}-6), 5.54-5.61(\mathrm{~m}$, 1H, H-7). ${ }^{13} \mathrm{C} \mathrm{NMR}\left(\mathrm{CDCl}_{3}, 101 \mathrm{MHz}\right.$ ): $\delta=14.45$ (q, C-12), 22.94 (t, C-10), 27.57 (t, C-3), 27.85 (t, C-8), 29.14 (t, C-2), 29.55 (t, C-9), 31.89 (t, C-11), 33.31 (t, C-5), 80.7 (s, C-4), 122.57 (d, C-6), 134.66 (d, C-7), 177.26 (s, C-1). (Numbering as shown in Fig. 1.)

\section{REFERENCES}

1. Auburn, P. R., MACKenZie, P. B., and Bosnich, B. 1985. Asymmetric synthesis. Asymmetric catalytic allylation using palladium chiral phosphine complexes. J. Am. Chem. Soc. 107:2033-2046.

2. COHEN, N., LOPRESTI, R. J., and SAUCY, G. 1979. A novel total synthesis of $\left(2 R, 4^{\prime} R, 8^{\prime} R\right)$ - $\alpha$-tocopherol (vitamin E). Construction of chiral chromans from optically active, nonaromatic precursor. J. Am. Chem. Soc. 101:6710-6713

3. Furniss, B. S., HANNAFORd, A. J., SMith, P. W. G., and TATChell, A. R. 1989. Vogel's Textbook of Practical Organic Chemistry. 5th ed., Longman Scientific \& Technical, Essex, UK.

4. KURZER, F. 1963. Arylureas. Org. Synth., Coll. Vol. 4:52-54.

5. RAVID, U., SILVERSTeIN, R. M., and SMITH, L. R. 1978. Synthesis of the enantiomers of 4-substituted Ylactones with known absolute configuration. Tetrahedron 34:1449-1452

6. SMith, H. A., Huff, B. J. L., POWERS, W. J., and CAINE, D. 1967. The reduction-methylation of cyclohexenone derivatives. J. Org. Chem. 32:2851-2856.

7. TIetZE, L.-F. and EICHER, T. 1981. Reaktionen und Synthesen im organish-chemischen Praktikum. Georg Thieme, Stuttgart, Germany, p. 69. 